\title{
Late Campanian-Maastrichtian sequence stratigraphy from Kurdistan foreland basin, NE/Iraq
}

\author{
Fadhil Ahmed Ameen Lawa ${ }^{1}$
}

Received: 2 September 2017 / Accepted: 24 December 2017 / Published online: 10 January 2018

(C) The Author(s) 2018. This article is an open access publication

\begin{abstract}
The Kurdistan foreland basin (NE Iraq) was formed as a result of the ophiolite-radiolarites obduction of the Iranian plate on the Arabian Plate. Extensive fieldwork for the determination of nine facies associations has been integrated with the planktonic and large foraminifera and other macrofossils biostratigraphic data in order to identify the sequence stratigraphic framework of the studied (late Campanian-Maastrichtian) successions comprising the Shiranish, Tanjero and Aqra formations. The studied successions are identified sensu Vial et al. (Payton CE (ed) Seismic stratigraphy application to hydrocarbon exploration memoir of the American association of the petroleum geologists, Tulsa, vol 26, pp 49-62, 1977) concepts, as three third-order depositional systems, within one major second-order depositional system, which is bounded by a sequence boundary of type one at its base and top. The Late Campanian-Early Maastrichtian third order is bounded by a middle Campanian gap as a sequence of boundary type one. The rapid drowning starts with planktonic foraminiferal-rich mudstone which indicates pre-flysch facies associations within starved foreland basin conditions and maximum flooding surface (MFS175). The sea level fell by the Early Maastrichtian, as characterized by a sequence boundary of type SBT2. The distal, medial and proximal turbidites flysch facies of the Tanjero formations manifest the second third-order depositional system. This may indicate a progressive shallowing upwards and characterized by MFS 180, which is placed at the top of the last planktonic-rich shale parasequences. The last third order is represented by rudist (Hippurites)-dominated carbonate parasequences (Late Maastrichtian-Aqra formation). The aggradational stacking pattern of the rudist lithosomes indicates the last MFS 190 during the Maastrichtian greenhouse. The sequence boundary is of type one which separates the Palaeocene molasses of Swais Group from the Maastrichtian sequence in the imbricated zone, while in the high folded zone it is replaced by Kolosh siliciclastic (Palaeocene) due to migrations of the Kurdistan foreland basin depocentre towards south-west. The reactivation of the deep-seated transversal faults is in addition to the sea level changes with south-westwards migration of the Zagros deformations front controlling the late Campanian-Maastrichtian supersequences framework.
\end{abstract}

Keywords Kurdistan foreland basin · Northern Iraq · Late Campanian-Maastrichtian · Sequence stratigraphy

\section{Introduction}

The Zagros Mountains of the Kurdistan region (NE/Iraq) are a spectacular example of the Cretaceous obduction/ subduction processes and the Tertiary orogenic event. They were formed as a result of collisions between the Arabian and Eurasian plates (Berberian 1995; Agard et al. 2005; AlQayim et al. 2012; Lawa et al. 2013). The Kurdistan foreland basin expresses the whole stratigraphic and tectonic

Fadhil Ahmed Ameen Lawa

fadhil.ameen@univsul.edu.iq

1 Department of Geology, University of Sulaimani, Sulaymaniyah, Iraq events in their supersequences and manifests shallowing upwards sequences along the north-eastern margin of the Arabian plate during the last Mesozoic Tectonic Megasequence (TMSAP 9). The studied area is considered to be a north-western continuation of the Iranian Zagros Mountains. Burberry and Jackson (2011), Burberry (2015), Zebari and Burberry (2015) all indicate the influence of the basement fault on the morphology of the sedimentary basin, in Kurdistan region during the Cretaceous. In this work, we clarify the generation and development of that basin during the Late Campanian-Late Maastrichtian through construction of the sequence of stratigraphic frameworks. That is based on the identification of facies associations, fossils assemblages, and parasequences analyses, stacking patterns and depositional 
system orders or the geometry of deposits. Also, we identify the type and duration of the sequence boundaries, the gap causes and their durations, in different tectonic zones, as well as along the Zagros trend. The parasequences of each stratigraphic unit have led to improved understanding of how parasequence stacking patterns develop in both time and space within the Late Cretaceous sedimentary basin.

\section{Geological setting}

The Zagros orogenic belt consists of four tectonically related parallel zones, following the classification of Agard et al. (2005); these zones, from south-west to north-east, are: low folded thrust zone (LFTZ), high folded thrust zone (HFTZ), imbricated zone (IZ) and Zagros Suture zone (ZSZ) (Fig. 1).

The main structural trend is north-west-south-east (NW-SE, in Sulaimani and Erbil area) and changes to Taurus (E-W trend, in Dhouk area) with less complexity towards Arabian platform. The structural complexity in the imbricated zone associated by the development of minor mesoscopic structures on the main folds. The high folded thrust zone is characterized by double plunging asymmetrical anticlines that with relatively of wider synclinal between the major anticlines. The studied Cretaceous successions are exposed in the core and limbs of those structures. The low folded thrust zone (Kirkuk embayment) almost characterized by a series of long echelon anticlines and separated very wide synclines. The

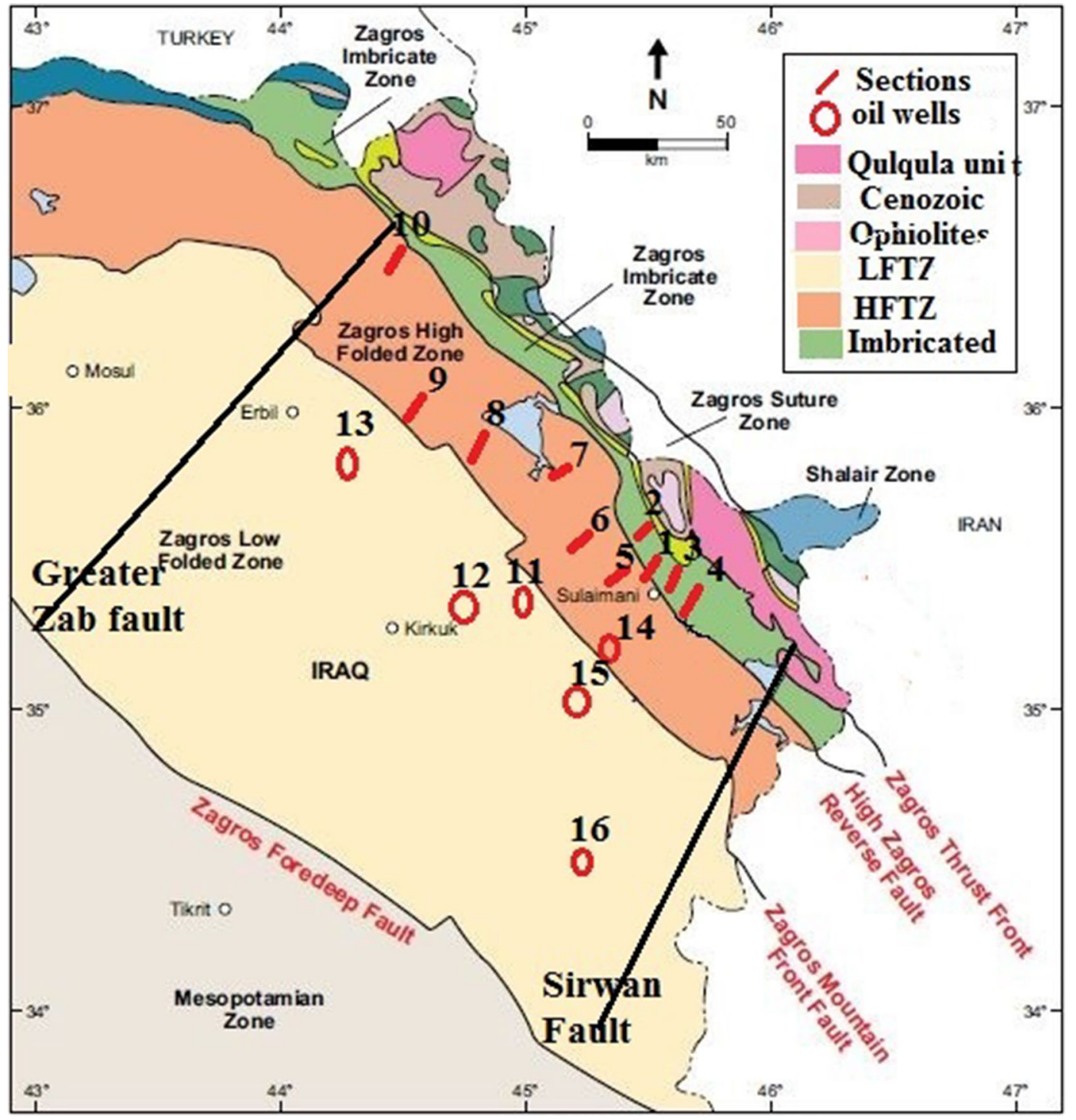

Fig. 1 Location map of the studied sections (1-Qaywan, 2-Konamassy, 3-Bazageer, 4-Alasiaw, 5-Mirgapan, 6-Zeywey, 7-Qarasirt, 8-Khalakan, 9-Smaqwly, 10-Choman) and wells (11-Miran, 12-Chamchamal, 13-Taq Taq, 14-Qaradagh, 15-Sangaw and 16-Sarqala well) 
three mentioned tectonic zones are dissected by NE transversal deep faults (Sirwan and Greater Zab faults) that influence on the basin palaeo-configuration and sediment nature types, distributions and variations (Fig. 1). The Late Cretaceous successions of Iraq (Kurdistan foreland basin) are of high importance for hydrocarbon potentiality, and hence the lithostratigraphic units have been studied from different geological viewpoints by several authors (Al-Mehaidi 1975; Kassab 1979; Al-Rawi 1981; Abdul Kireem 1986; Jaza 1992; Lawa et al. 1998; Aziz et al. 2000; Karim 2004). The Late Campanian-Late Maastrichtian supersequences are manifested by the Shiranish, Tanjero and Aqra formations in the Kurdistan foreland basin (Fig. 2; Table 1). The Late Cretaceous system outcrops in the imbricated and high folded thrust zones and can traced via several wells drilled in the low folded thrust zone, where these combine with both a reduction in the studied supersequences' thickness from more than $2 \mathrm{~km}$ (Sirwan valley) to less than $400 \mathrm{~m}$ (Sarqala well) and the disappearance of the flysch and reefal facies Table 1.

\section{Stratigraphy}

A foreland basin was formed on the northern margin of the Arabian plate during the Turonian-Eocene in response to loading of the crust by a thrust sheet formed as a result of compression on the north-east margin of the Arabian plate by the Iranian plate (Jassim and Goff 2006). The Late Campanian-Late Maastrichtian stratigraphic column represented by the succession comprised of Shiranish formation (Campanian-Early Maastrichtian), Tanjero formation (Early to Middle Maastrichtian) and Aqra formations (Late Maastrichtian) (Table 1; Fig. 2). In this foreland basin, the pre-flysch facies of Shiranish formation overlain conformably by the flysch facies of Tanjero formation and terminated by the reefal facies of Aqra formation. Such facies associations show turnover from under fill (starved basin) to overfill conditions within major trends of shallowing upwards successions, palaeo-climatic changes, and associated by depocentre migrations. The overfill condition during the palaeogene, in the imbricated zone, was indicated by the deposition of more than $2000 \mathrm{~m}$ red continental siliciclastics of Swais Group,

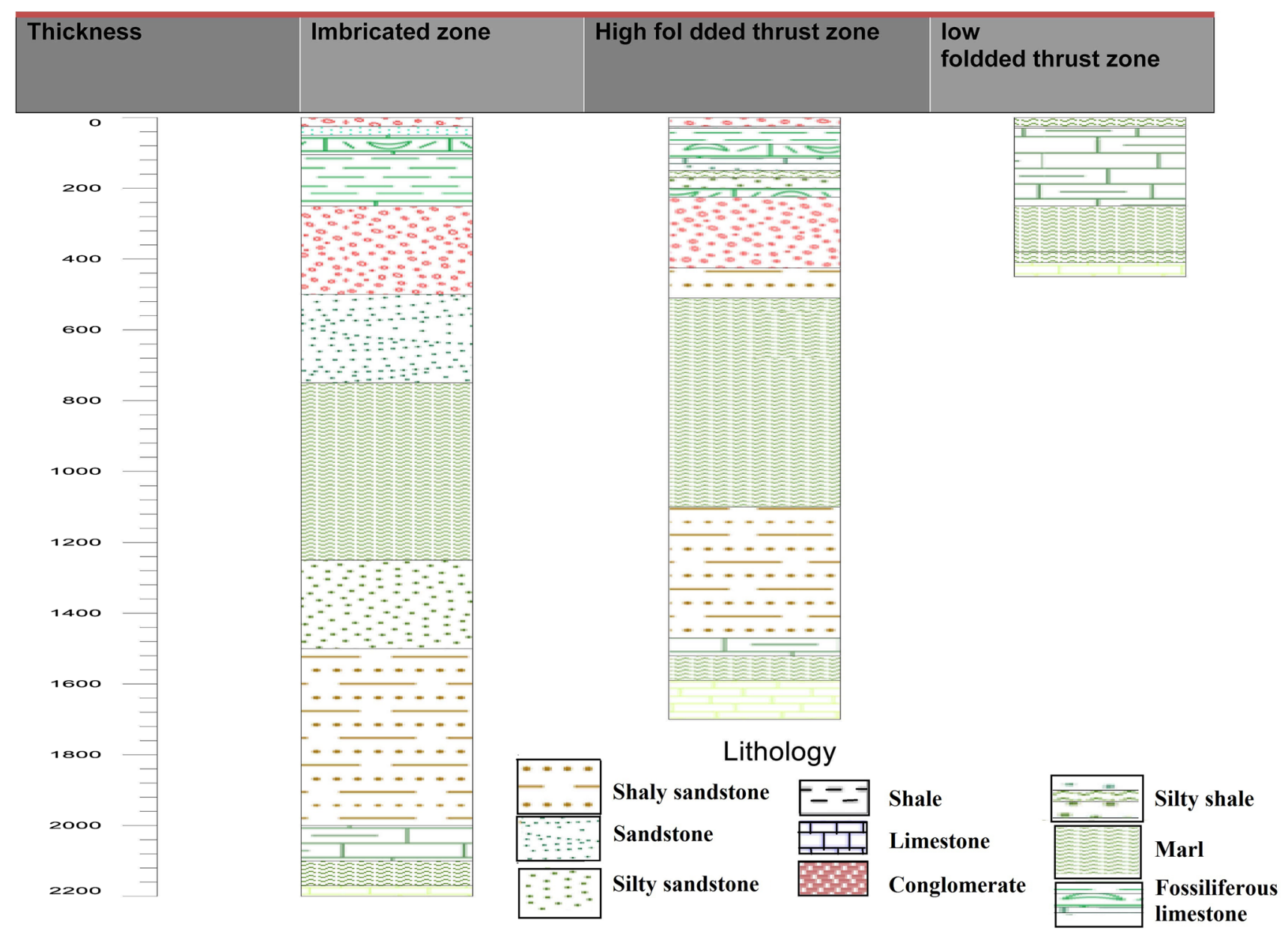

Fig. 2 Lithostratigraphic correlation of the Late Campanian-Late Maastrichtian in Kurdistan foreland basin 


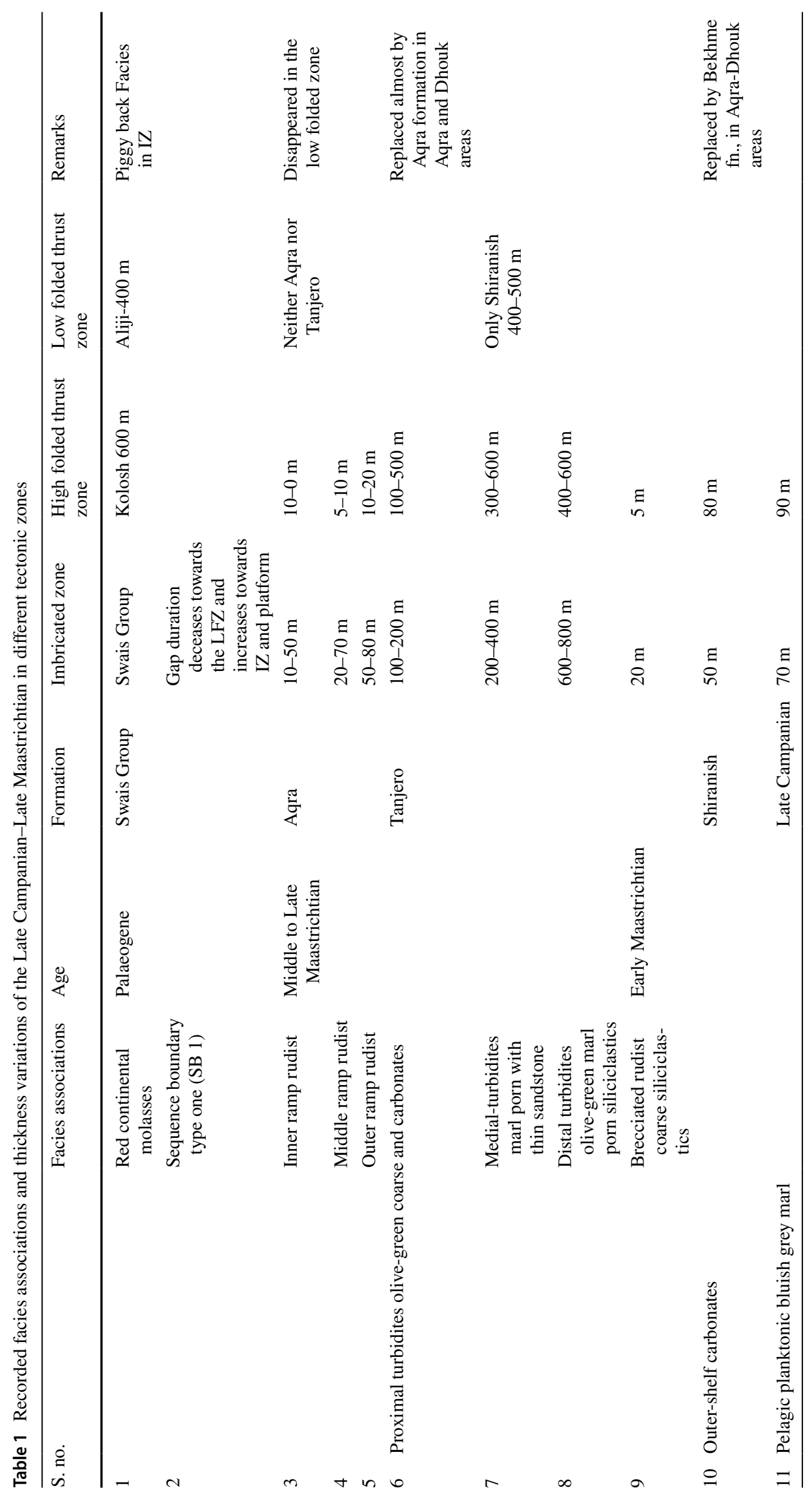


while in the high folded thrust zone manifested by the migration of the foreland basin depocentre and characterized by the deposition of turbidites siliciclastics of the Kolosh formation (Palaeocene). The later change to the synchronous facies of the Aliji formation in the low folded thrust zone (Kirkuk embayment) (Table 1; Fig. 2).

\section{Shiranish formation}

This unit is considered as the pre-flysch facies of the foreland basin and as a part of the Tectonic Megasequence of the Arabian plate TMSAP 9, which is exposed in the imbricated zone, high folded thrust zones and within subsurface sections of the low folded thrust zone (Kirkuk embayment), (Jassim and Goff 2006; Aqrawi et al. 2010; Sharland et al. 2004; Lawa et al. 2013). From lithological point of view, this formation consist of a very homogeneous successions of bluish grey to dark grey hemiplegic/pelagic marl and marly limestone, glauconitic at the upper and lower boundaries, without any sandstone beds. The dominant facies comprised mainly of fine-grained wackestone, and mudstone, rich in planktonic foraminifera, few small benthic foraminifera.
The later increase upwards with increasing of marly limestone beds, which is also intensively fractured (Fig. 3, 1-7). In the type section near Shiranish Islam village north-east Zakho, Shiranish formation is about $225 \mathrm{~m}$ thick, while in the studied outcropped sections from imbricated zone, it reaches $120 \mathrm{~m}$ thick, while in the high folded thrust zone about 150-200 m, and almost reaches $400 \mathrm{~m}$ in Kirkuk embayment (LFTZ), associated by the disappearance of the Tanjero and Aqra formations. The foraminiferal assemblages within Shiranish formation are interpreted as representing outer-shelf to middle slope environments, between ca $200 \mathrm{~m}$ to at least $600 \mathrm{~m}$ water depth maximum water depths in the late Campanian, followed by shallowing into the Early Maastrichtian, (Jaff et al. 2014). The lower contact with the underlying Kometan formation considered as unconformable boundary and indicated by the presence of a glauconitic pebbly sandstone bed of around $0.5 \mathrm{~m}$ at the base of the of Shiranish formation (Fig. 3, 1-3). They may indicate a very slow rate of deposition or period of non-deposition, associated by mass death of ammonites and presence of two hard ground surface; such condition is recorded from several outcrop sections (Qamchuqa, Zewe, Sarachinar, Merga pan and
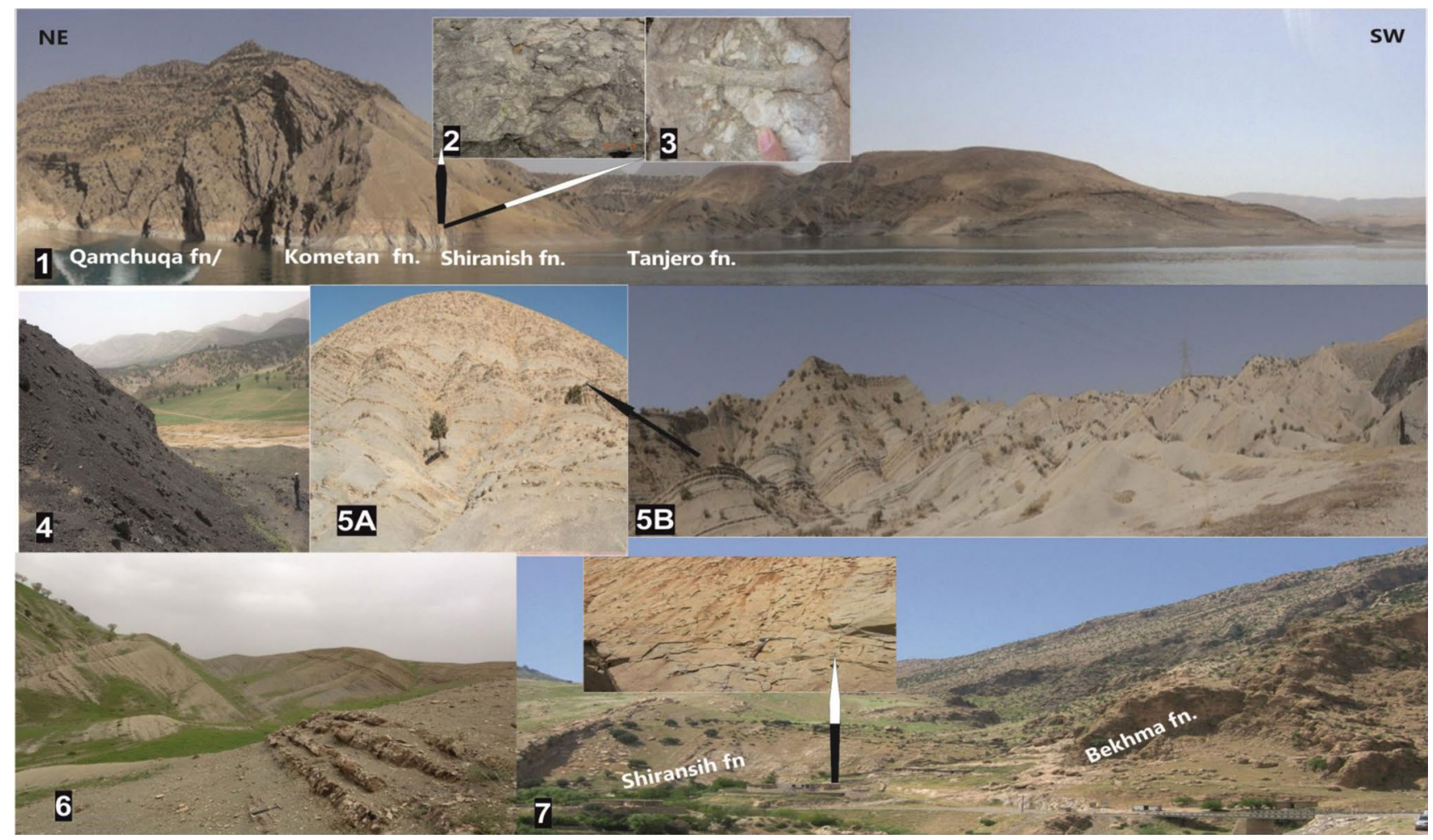

Fig. 3 1. Qarasirt section/Dokan lake, high folded thrust zone. 2. Hard ground surface at the base of Shiranish fn. 3. Glauconite at the Kometan/Shiranish formations boundary. 4. Bitumen seeps from marl-dominated part, Shiranish fn. (Alasiaw section). 5a. Increasing of carbonates at the upper parts of the Shiranish fn, imbricated zone. 5b. Marl-dominated sequence in the lower part of Shiranish fn. 6 .
Conformable, gradational contact between Shiranish and Tanjero formations. 7a. Shiranish formation underlain by Bekhme fn., and overlain by Kolosh, in Bekhme Gorge. 7b. Pyritic, bioturbated and condensed section at the middle part of Shiranish fn., in Bekhme Gorge section 
Dokan) and recorded by Karim (2004), Aqrawi et al. (2010), Jaff et al. (2015), Al hamdani (2015). Towards Dhouk and Zakho area, the Shiranish formation unconformably overlies the Bekhme formation (Al Mutwali and AL-Haidary 2012) and unconformably overlain by Kolosh formation. (AL-Wazan 2007) (Fig. 1, 7). The upper contact in the high folded zone (Sulaimani and Erbil area) with Tanjero formation is conformable transitional, gradational contact, without any indication for non-deposition or erosion, usually placed at the base of the first sandstone bed above Shiranish formation, (Fig. 2, 1,2). The upper contact, in the low folded zone (Jambour-46, 49, Pulkhana 1-7, Sarqala-1-2, Kirkuk-306, 106 wells), with the Aliji formation (Palaeocene) seems to be unconformable surface, with fossils break indicating Cretaceous/Tertiary boundary (Bellen et al. 1959; Buday 1980; Al Qayim et al. 2008; Jaff et al. 2015). The age of the Shiranish formation is Late Campanian to Maastrichtian, but it does not extend to the Late Maastrichtian (Kassab 1975, 1979; Jaff et al. 2014). Based on the planktonic foraminifera, the age extends from the Late Campanian to Early Maastrichtian in most parts of Sulaimani and Erbil area and extends to Middle Maastrichtian in Kirkuk oil field Kassab (1979), AL-Wazan (2007) emphasized that based on planktonic zonation samples from well (K-306).

\section{Tanjero formation}

The deposits of this unit indicate flysch facies within the foreland basin and recorded from Sirwan valley (type section) about $87 \mathrm{~km}$ south-east of Sulaimani city, by Dunnington 1952 in (Bellen et al. 1959). This unit consists of rhythmic alternation of olive-green sandstone, marl, calcareous shale and sandstone or siltstone, about $2018 \mathrm{~m}$ thick in the type section (Figs. 4, 5). This unit is recorded only from the imbricated and high folded thrust zone and disappears towards the low folded thrust zone. This appearance of the calcareous sandstone (calcarenite) and increase in the sandstone beds both in grain size (calcrudites) and bed thickness (from few centimetres to few metres) differentiate this unit from Shiranish formation. The erosive beds of the turbidites deposits are characterized by flute cast, graded bedding, ball and pillow, cross-lamination, parallel laminations and large trace fossils/and or plant remains (Figs. 4, 1-6; 5, 2-7). The lower part (about 200-400 m thick) is characterized by a thick marl bed alternating with a lensoidal bed of conglomerates, and a bioturbated sandstone bed shows progressive increase in marl and shale beds and disappearance of the conglomerate in the middle part (500-1000 m thick); the marl porn parts are rich in planktonic foraminifera. The upper part (200-300 m thick) shows the alternation of a pebbly sandstone bed and thick sandstone with marl and carbonates. Based on most of the previous studies (Buday 1980; Al-Rawi 1981; Abdel Kireem 1986; Jaza 1992; Stevanovitic et al. 2003; Ahmed 2014; Aqrawi et al. 2010) and this work field observations, the thickness of the Tanjero formation shows reduction from about $2000 \mathrm{~m}$ (Sirwan valley) in the high folded thrust zone towards $500 \mathrm{~m}$ (Chamchamal well) in the low folded thrust zone and disappears in Kirkuk wells. The facial change towards Dhouk and Zakho area (from Zagros to Taurus trend) associates with the disappearances of the flysch facies and predominates of the reefal carbonate of Aqra instead of Tanjero formation during the Maastrichtian. The second major facial changes from Sulaimani to Kirkuk (from foreland basin to depocentre) associate also with the disappearances of Tanjero and Aqra formations, where it is replaced only by Shiranish formation as the case in most of the wells in Kirkuk embayment including Sarqala well 1 and Kirkuk oil fields. The deposition of the Tanjero and Aqra formations coincide in time (simultaneous) with the time of the depositions of upper part of Shiranish formation. In the studied outcrop sections and based on planktonic, the age of the Tanjero formation is considered to be of Early to Late Maastrichtian age, by several authors (Kassab 1975; Minas 1997; Abdel Kareem 1986; Lawa et al. 1998; Sharbazheri 2007).

\section{Aqra formation}

This unit represents the reefal member of the foreland basin that overlies the Tanjero formation in the imbricated and high folded zone and disappears in the low folded zone. In the type section of the Tanjero formation, a thick fossiliferous limestone, rich in rudist and large foraminifera, is recorded at the upper part of that section by Bellen et al. (1959), without nomination as Aqra formation. AlMehaidi (1975) nominated that uppermost part of Tanjero, in Chwarta-Mawat area, as tongue of Aqra formation. Lawa et al. (1998) emphasized that the fossiliferous carbonates (rich in rudist and large foraminifera) show interfingering between the upper parts of Tanjero with Aqra formation and concluded Abathomphalus mayaroensis subzone of Late Maastrichtian age for that succession. The type section of Aqra has been described for the first time by Kuhn and Kumel (1939), and then it is selected as type section from Geli Sheikh Abdul Aziz, Aqra City, Beentte 1940 in Bellen et al. (1959), where they identified Aqra formation as massive carbonates slightly siliceous or argillaceous and impregnated with bitumen. Aqra formation in all studied outcrops are characterized by bluish to brownish grey limestone, which is occasionally argillaceous or arenaceous, and very rich of large foraminifera (Loftusia, Ompahlocyclus, Orbitoides) and giant macrofossils, especially pelecypods among them rudist (Eoradiolites, Praeradiolites and Duriana), in addition to large echinoderms, gastropods, Exogyra, Gryphaea are also common (Fig. 6, 2-4). New species of Gyroconulina aqraensis have 


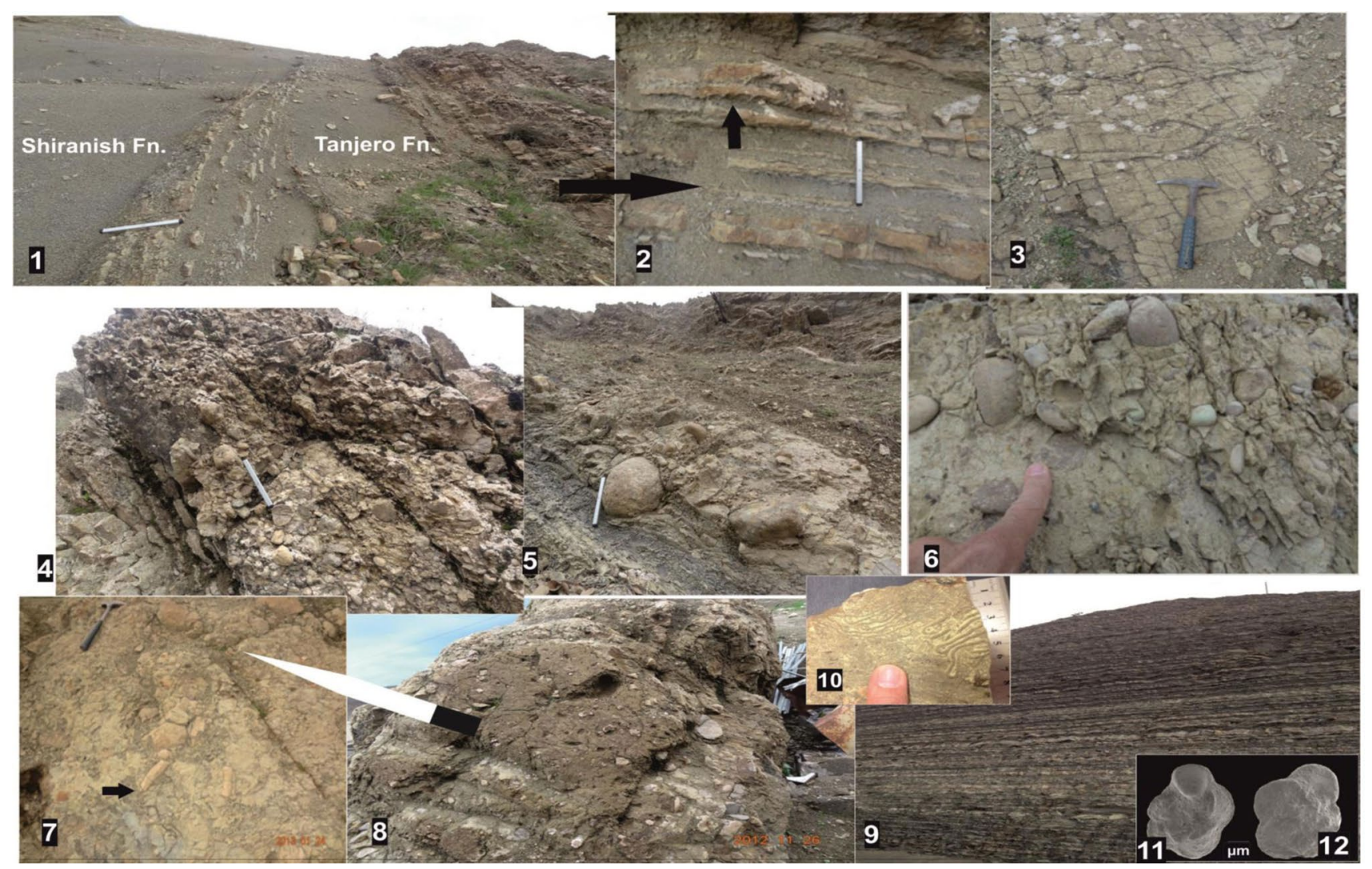

Fig. 4 1. Shiranish/Tanjero fns. conformable boundary. 2. Sole marks at the base of the first bed of sandstone. 3. Giant Planolites trace fossils at the top of sandstone (LST, second third order). 4 and 5. Conglomeratic facies associations at the lower part of Tanjero fn. 6 . Gravel and chert boulders within planktonic mudstone of Tanjero for-

been recorded from Aqra formation type section, by Lawa et al. (1986). The bed geometry and the macrofossil associations (rudist and other reef components), in addition to abundance of the large foraminifera, point to patchy reef depositional environment, within late Maastrichtian green house. During the quite calm, subtropical condition, the reef habituates are flourished by the shallow warm marine water, while due to siliciclastic influx, the reef and carbonate factory stopped and totally disappeared at the uppermost parts of Aqra formation. Slumped block and reef taluses can be recognized occasionally below Cretaceous/Tertiary boundary as the case in Dokan section (Fig. 7, 5-6) might indicate syn-sedimentary tectonic disturbance; such conditions are combined by the invasions of deltaic facies in the imbricated zone. The carbonates show an increase in thickness from few centimetres to few metres, to massive beds the whole carbonate successions, may reach $225 \mathrm{~m}$ in thickness as in Dole Beshk and Mawkaba sections (Figs. 5, 11, 12; 6, 1, 2) and decrease to $30-40 \mathrm{~m}$ in Sirwan, Dokan, Khalakan areas and Miran well. The remarkable disappearances have been detected mation. 7 and 8. Slumped rudist patch-reef blocks into low-stand system tract, lower part of Tanjero fn. 9. Distal turbidite facies within the middle part of Tanjero fn. 10. Nerites deep marine ichnofossils. 11 and 12. Planktonic foraminifera (Globotruncanadis-MFS-180) within the second third order, Tanjero fn

from Chamchamal well-1 and whole drilled wells in the low folded thrust zone (especially Kirkuk embayment).

\section{Methodology}

Extensive fieldwork was done along several transverse cuttings across the imbricated, high and low folded thrust zones, including ten outcrops of stratigraphic section and six wells (Fig. 1). The distribution of the outcrops is almost perpendicular to the NW-SE trending palaeoshoreline as indicated by regional work of Jassim and Goeff (2006). The outcrops data have been integrated with oil well data. Particularly, this approach is focused on analysing changes in facies (both laterally and vertically), taking in consideration the geometric character of strata and the identification of key surfaces (e.g. unconformities, bioturbated surfaces, coquina bands, condestae sections) to determine the chronological order of basin filling and erosion events. From the imbricated zone, the following section was described and sampled: 1-Qaywan, 2-Kona Massy, 3-Bazageer, 4-Alasiwa, 


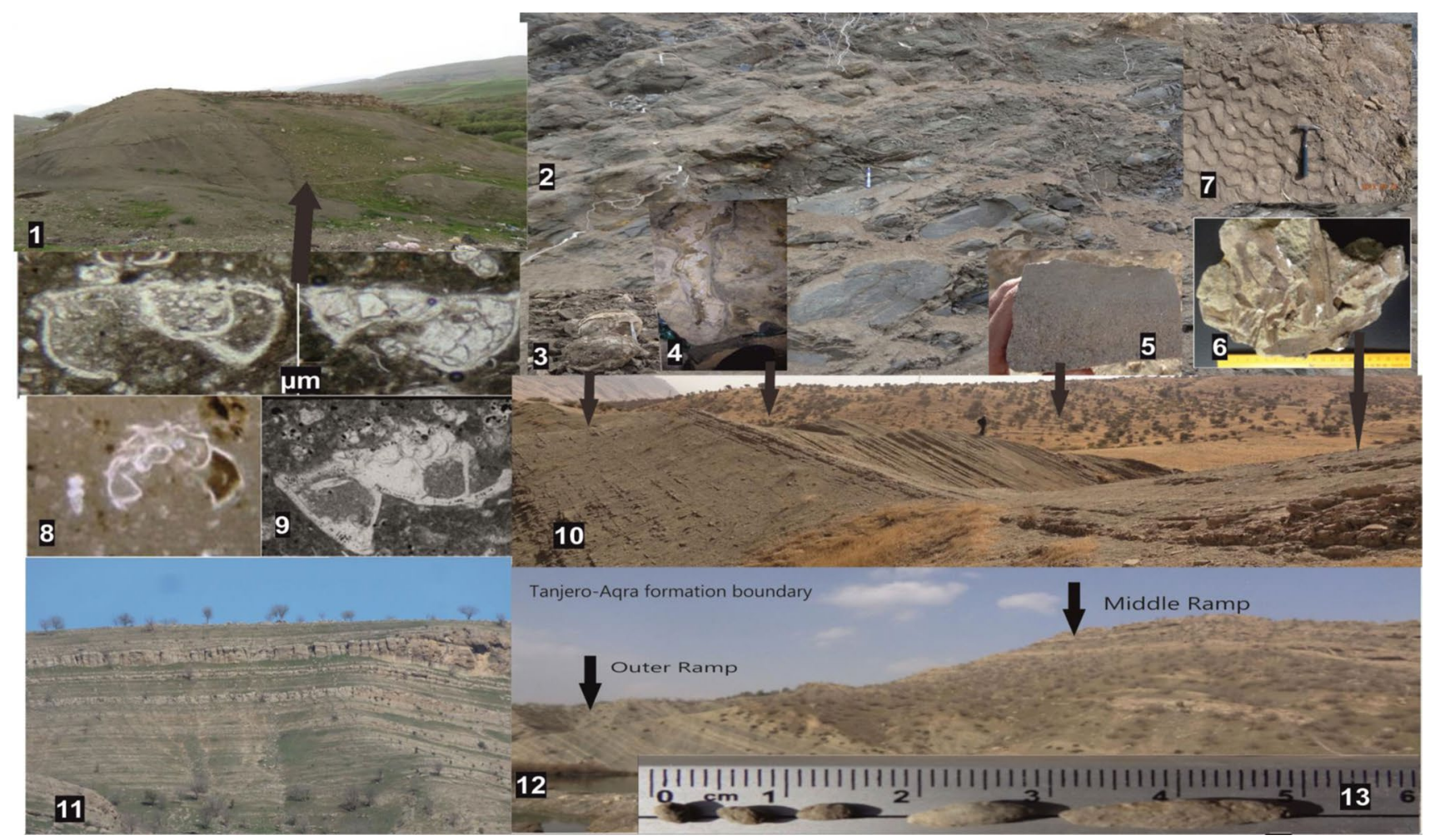

Fig. 5 1. Planktonic mudstone, within lower part of Tanjero fn. 2. Proximal turbidite facies associations, with thickened and coarser siliciclastics. 3. Ball and pillow structures. 4. Planolites ichnofossils. 5. Graded bedding turbidites. 6. Plant remains. 7. Ripple marks. 8 and 9. Planktonic foraminiferal facies within middle part Tanjero forma-

while from the high folded thrust zone the study sections are: 5-Mergapan, 6-Zeywey, 7-Qarasirt, 8-Khalakan, 9-Smaqwly and 10-Choman. They are traced and correlated with a stratigraphic succession from the oil wells, and they are: 1-Miran (Mr.1), 2-Chamchamal (Ch.1), 3-Taq Taq (TT.1), 4-Qaradagh (QD.1), 5-Sangaw south (SS.1) and 6-Sarqla (SQ-1). The parasequences and stacking pattern of the studied sequence were essentially based on the lithological, facies associations and biostratigraphic data, and also on the key surfaces (e.g. sequence boundaries and flooding surfaces) that, in combination with biostratigraphy, allow robust correlation. Also for palaeontological purposes, the planktonic, benthonic and large foraminifera were studied and analysed in more than 220 cooked samples and 188 thin sections. For cooking purposes, each sample was weighed, crushed and boiled for several hours, washed with tap water and dried and size-sorted using a set of different sieves; all specimens were picked and prepared for identification under a binocular microscope. Also, about 50 macrofossils have been identified of rudist, gastropods, pelecypods, ammonites, echinodermata and coral. tion. 10. Proximal turbidite facies associations within upper part of Tanjero fn., Dokan section. 11 and 12. Outer to middle ramp facies associations. 13. Increasing of Loftusia in size upwards from outer ramp to inner ramp. (Loftusia minor $23 \mathrm{~mm}$ to Loftusia elongata $70 \mathrm{~mm}$ )

\section{Facies associations}

\section{Pre-flysch facies associations (Fig. 1, 1-7)}

Mostly, they are represented by the marl and limestone facies of the Shiranish formation. All studied sections and wells consist of two major pre-flysch facies associations and are characterized by a monotonous succession of pelagic planktonic foraminifera-rich marl without sand influx intercalations. The first facies association is mostly composed of blue to bluish grey marl rich in planktonic foraminifera, about $100 \mathrm{~m}$ thick and mostly of the late Campanian age that is spread over most of the imbricated, high folded and low folded thrust zones of Kurdistan region. The globotruncanides mudstone- and wackestone-dominated microfacies within this facies mostly makes up the lower part of the Shiranish formation and it usually consists of planktonic mudstone and wackestone from the Middle Campanian age (Globotruncana fornicate, Globotruncana aegyptiaca, Globotruncana Globotruncana stuartiformis, Globotruncana elevata and Globotruncana ventricosa assemblages zone), most probably deposited in the upper part of the Bathyal zone (Table 2; Figs. 2 and 8). 


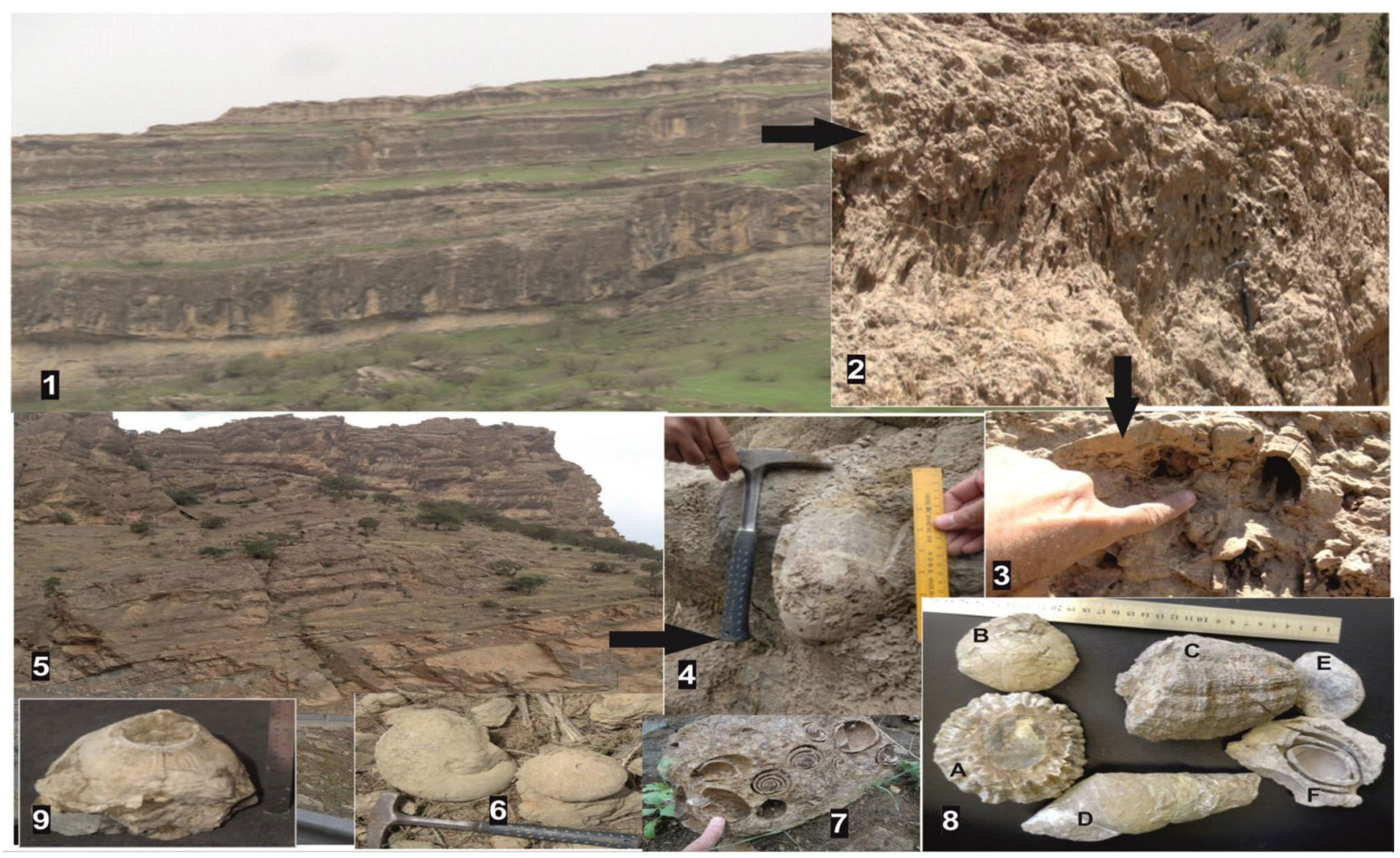

Fig. 6 Massive middle ramp carbonates. 2. Rudist reef body. 3. Preradiolites predominated in the middle ramp facies associations from Aqra fn. 4. Giant rudist solitary Hippurites (Duriana) from Sura Qalat section, imbricated zone. 5. Massive Aqra carbonate middle platform, Choman section. 6. Ammonites and echinoids association (Maastrich- tian green house). 7. Gastropods (Acteonella) Coquina band within Aqra reefal facies associations. 8. A. Glycemeris, B. Echinoids, C. Duriana (rudist), D. Turritella (gastropods), E. Gryphaea, F. Acteonella all from Aqra fn. 9. Right valve of giant rudist from middle ramp facies associations

\section{The second dominate pre-flysch facies association is represented by the outer-shelf marly limestone and limestone sequences of the Shiranish formation} (Fig. 1, 4-5)

This part is manifested by the predominance of limestone planktonic mudstone and wackestone facies which show progressive changes to Bolovinoides-rich carbonates. Accordingly, the benthonic-planktonic ratio increases and the marl beds decrease in frequency and thickness. The upper boundary with the overlying sequence is marked by a prominent conformity associated with a shift in palaeodepth from deeper to remarkably more shallower conditions and towards more siliciclastics influx as well as tectonic activity (Abdul kireem 1986; Ahmad (2014). Due to a rapid siliciclastic influx and turbidity effect, the planktonic and benthonic foraminiferal assemblages are barren in the uppermost 2-5 $\mathrm{m}$ of the Shiranish formation in the imbricated zone sections. The upper boundary of this facies, with the overlying one, is characterized by the first appearance of sandstone beds, about $10-20 \mathrm{~cm}$ thick of an olive-green colour bioturbated, with flute cast base, and occasionally argillaceous (Figs. 3, 6; 4, 1-2). The relatively thin pre-flysch facies $(150 \mathrm{~m})$ associations are overlain by very thick flysch facies of Tanjero formation $(2000 \mathrm{~m})$ and the predominant flysch facies association are: conglomeratic rudstone facies associations, distal turbidite facies, medial turbidite facies, and proximal turbidite facies. They are described as follow:-

\section{Conglomeratic rudstone facies associations (Fig. 4, 4-6)}

This rudstone with sub-rounding to sub-angular bioclasts, chert fragments and ophiolites occurs in various sections of the imbricated zone (Zarda bee, Bazageer, Dlobeshk, Kona Massi sections). The whole components are badly sorted fragments of rudists, corals, echinoderms and gastropods, with an average grain size that may reach several centimetres, though they vary considerably from layer to layer and may exceeds 30 centimetres (Fig. 4, 5). The conglomeratic rudstone beds are rarely thicker than a few decimetres. The layering (normally expressed as variations in grain size) often displays low-angle cross- or sub-horizontal

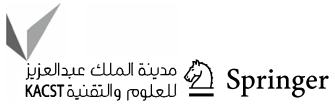




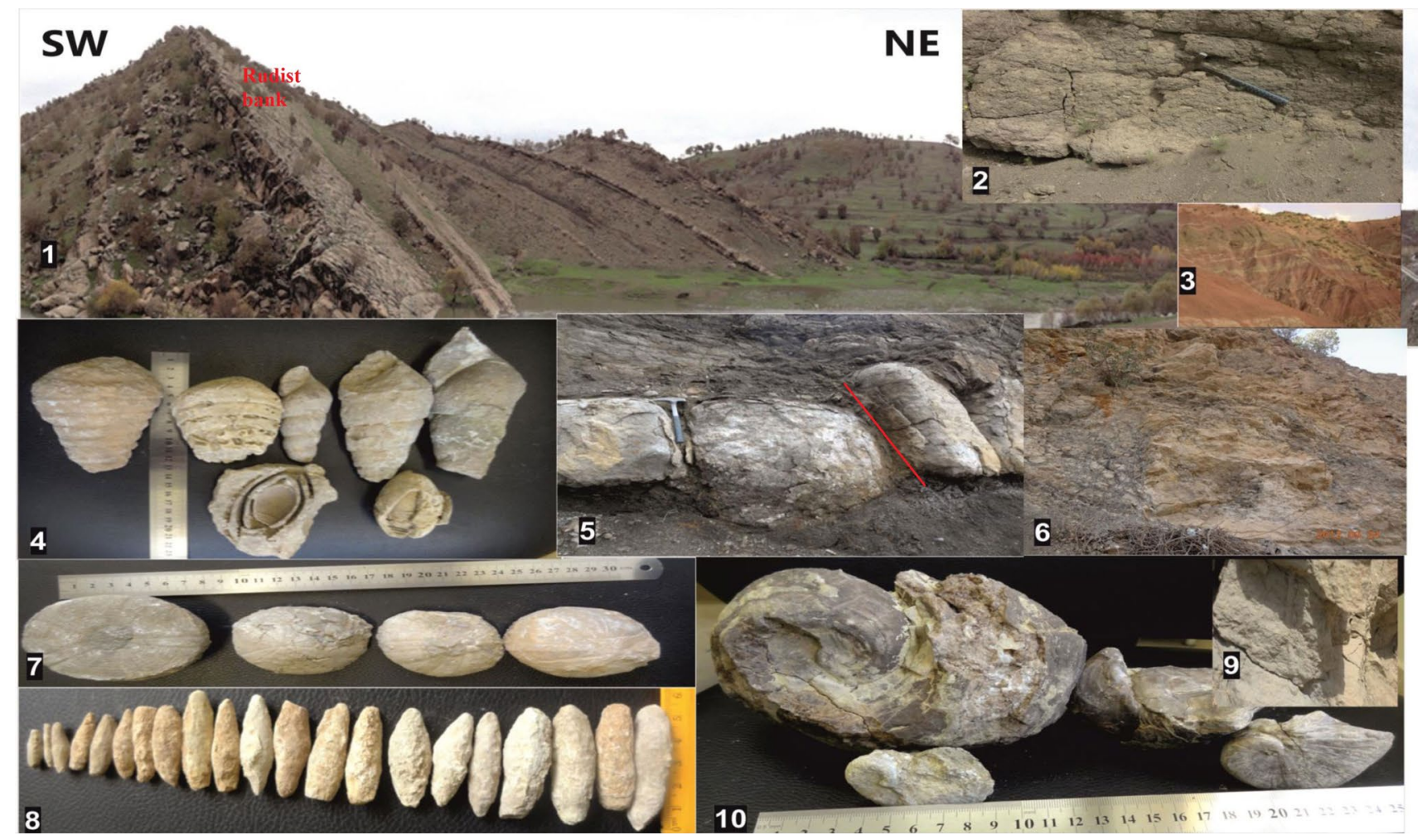

Fig. 7 1. Upper part of Aqra fn. 2. Incised valley fill (SBT.1). 3. Swais Group. 4. Turritella and Acteonella. 5. and 6. Slumped blocks (Dokan section). 7. Echinoides from Zardabee section. 8. Loftusia from lower to upper parts of Maukba section. 9. Skolithos. 10. Exogyra (from Bazageer section)

huge thickness may also result from repetition due to a thrust fault, especially in the imbricated and high fold thrust zones which consist of a parasequences that comprised of very thick marl and thin beds of sandstone. The planktonic mudstone facies alternates with thin parallel laminated and extensively bioturbated sandstone and points to the Early Maastrichtian Contusotruncana contusa interval zone (Table 3). The ideal distal facies association consists of predominantly sheet-like turbidites with a shale and/or marl cap. Thin sandstone beds generally alternate with very thick marl at intervals of about 20-40 $\mathrm{m}$. The most common and essential rock types are fine- to medium-grained dark grey sandstone and shale, or a sandstone and greyish green marl interlayer with greyish green thin sandy limestone, silty sandstone, silty shale and silty marl of subsidiary rank. The thin sandstone beds are characterized by a $\mathrm{Td}$ and Te Bouma sequence horizon. Towards the top of this facies association, the shale bed decreases both in thickness and rate of repetition and is replaced by marl or silty marl capping the rhythmic cycles of a predominantly siliciclastics sequence.

These facies associations represent the lower part of the Tanjero formation range between 600 and $1000 \mathrm{~m}$; such 
Table 2 Generalized distribution chart of the planktonic foraminifera in Shiranish and lower part of Tanjero formation

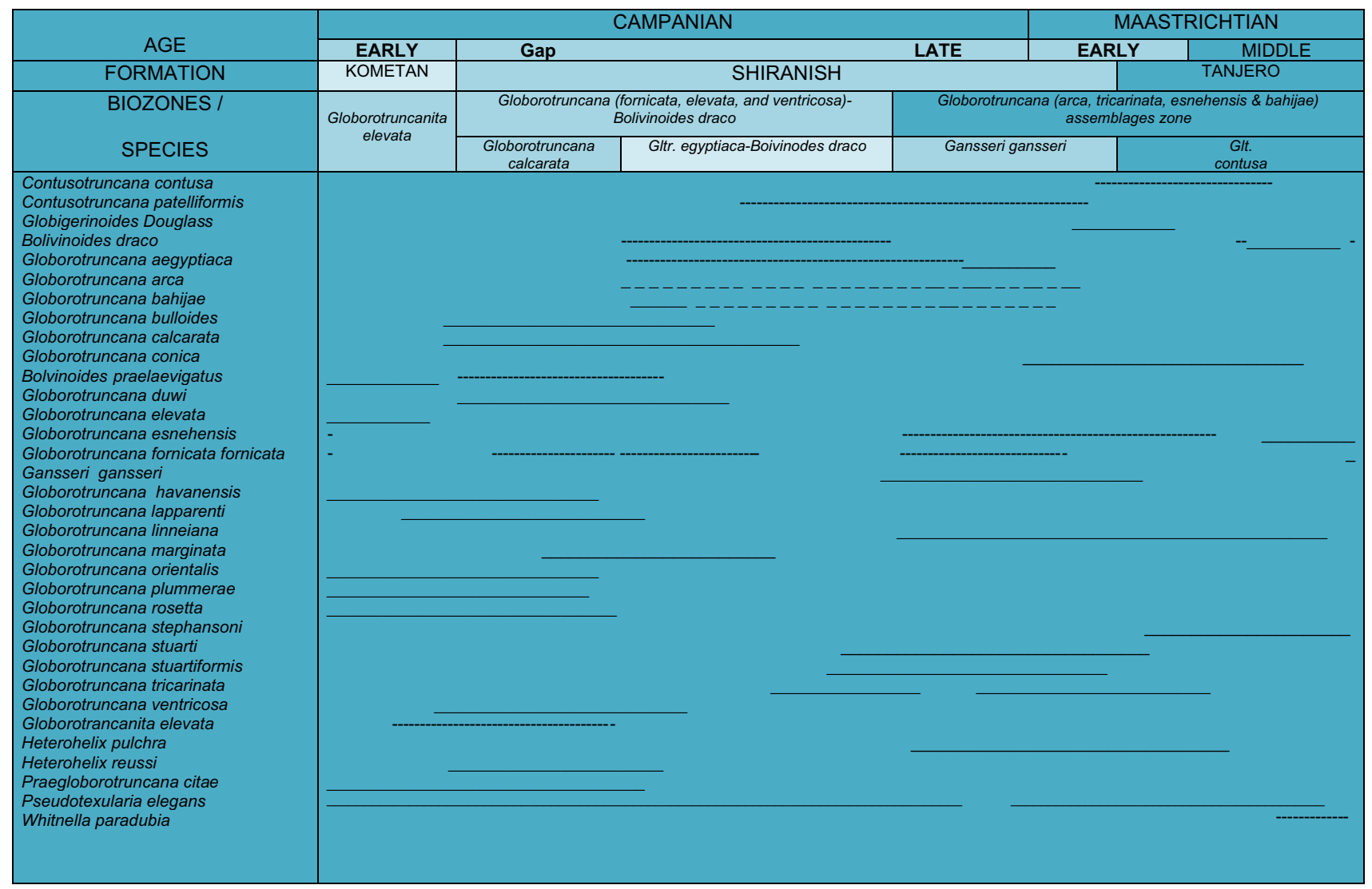

\section{Medial turbidite facies (Fig. 5, 1-2)}

This facies association represents the middle part of the Tanjero formation, which is about $300-600 \mathrm{~m}$ thick and recognized from all sections in the imbricated zone and high folded zone, but dies out in the low folded thrust zone. This facies is characterized by thick parasequence that starts with very thick marl horizons (about 10-20 m thick and may reach $80 \mathrm{~m}$ ) that change upwards to medium- to thick-bedded, olive-green, cross-laminated and bioturbated sandstone beds, of medium to coarsegrained sandstone with plant remains. The planktonicrich marl with a diagnostic appearance of Early to Early Middle Maastrichtian age is characterized by increasing benthonic foraminifera (Bolivina, Bolivinoides, Uvigerina, Textularia, Fissoelphidium and Chrysaldina (Table 3)).

\section{Proximal turbidite facies (Fig. 5, 2-10)}

This facies is of Middle to Late Maastrichtian age and mostly represented by thick conglomeritic horizons and coarse-grained pebbly sandstone beds that are associated or occasionally mixed with the reefal facies from the Aqra formation. The sandstone bed is of $\mathrm{Ta}, \mathrm{Tb}$ and $\mathrm{Tc}$ turbidite Bouma horizons and shows slumped structures associated with the appearance of large foraminifera, as well as patchreef carbonates. (Fig. 5, 2-10). Ball and pillow sedimentary structures of large size with large Thallassinoides and Skolithos and Planolites ichno-facies increase upwards, and the upper Bouma divisions are rich in plant remains (Fig. 5, 3, 4, 6). The shale ratio decreases, while the marl ratio increases. On the other hand, the sandy conglomeritic limestone increases and shows remarkable decrease in thickness towards the south and south-western parts of the study area. The Maastrichtian reefal facies are recognized at the top of the Tanjero formation (Bellen et al. 1959; Aqrawi et al. 2010) even in the type section of the Tanjero formation and from other locations like the Mergapan, Dokan, Khalakan and Miran wells. The reefal facies associations (outer ramp, middle ramp and inner ramp) are described as follow.

\section{Outer ramp facies association (Fig. 5, 11-13)}

The lower Aqra layers were laid down in open marine conditions and are represented by a laterally equivalent shaley facies and other clastic facies assigned to the upper part of the Tanjero formation and communicating and prograding along a side edge to the upward gradient attitudes. The commonly recorded microfacies are planktonic foraminifer's 


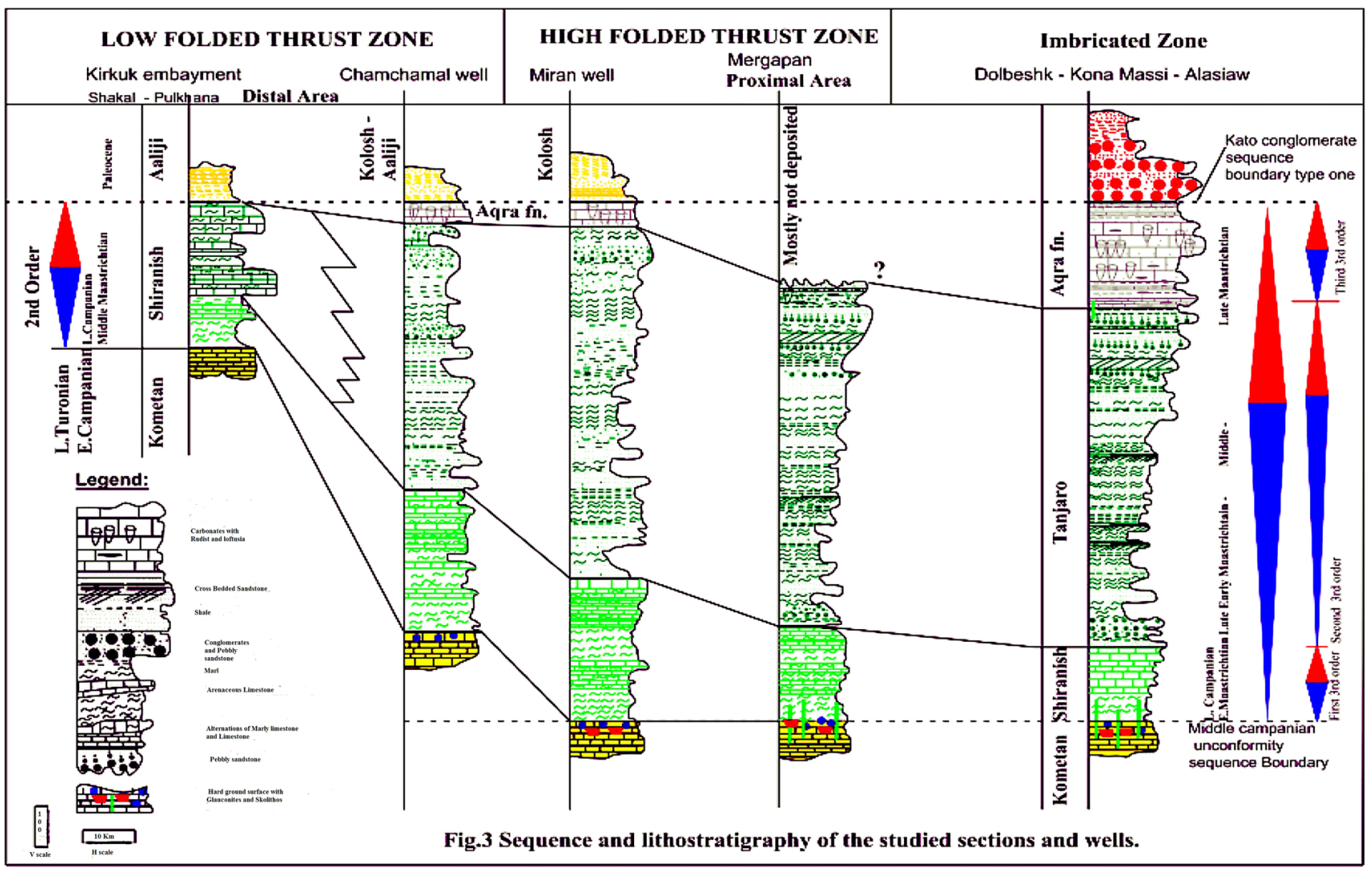

Fig. 8 Sequence and lithostratigraphy of the studied sections and wells

wackestone-packstone, Loftusia-Omphalocyclus bioclasticcorallinacean- packstone-grainstone (the most common one), especially when they show inter-fingering with proximal turbidites in the studied imbricated sections.

\section{Ramp facies associations (Fig. 6, 1-8)}

The middle parts of the Aqra formation were deposited in lower energy settings with more frequent evidence of reefal conditions, reflecting the ramp settings of shallow marine, warm and relatively stable conditions. The common patchy reef builders are the giant Hippurites (rudists), giant gastropods such as Acteonella and Turritileds, and giant echinodermata. The giant Gryphaea, within massive limestone, is about 3-10 m thick (Fig. 6, 4-8). They are also combined with large foraminiferal assemblages of Loftusia, Omphalocyclus and Orbitoides. Rudist bafflestone ramp facies reaches its maximum thickness in the imbricated zone, as in the Kona massi and Bazageer sections, it is about $100 \mathrm{~m}$ thick, which shows a reduction to $50 \mathrm{~m}$ at Miran well and recorded from the Khalakan sections. Microfossils are large benthic foraminifera: Loftusia elongata, Loftusia persica, Loftusia morgani, Pseudorbitoides, Orbitoides media, Orbitoides tissotti, Omphalocyclus macroporus and
Lepidorbitoides minor. The rudist boundstone facies almost consist of rudist solitary, and/or patchy reef (Prearadiolites, Daurina), gastropods (Acteonella Turbo, Turritella), with green calcareous careous algae (Dasycladaceae) are common too. Other large pelecypods (Gryphaea, Glycemeris), echinoderms, in addition to the large foraminifera, are also common and point to bioherm rudist body of patchy nature within massive limestone intervals.

\section{Inner ramp facies associations (Fig. 7, 1-12)}

Three subfacies are recognized within the inner ramp facies association at the uppermost parts of the study sequence, which includes bioclastic miliolids green algae packstone, miliolid-intraclast bioclasts and carbonate mudstones (laminated mudstone, fossiliferous mudstone and algal mudstones, with rudist, Orbitoides media, Orbitoides apiculata, Omphalocyclus macroporus, Dasycladaceae and echinoderms). Ross (1992) interpreted these sediments as "backreef gravel", which formed small island similar to the reef flats of Holocene pacific reefs or shingle reef islands of the Great Barrier Reef. The upper most part of this facie shows, occasionally, reworked rudist fragment within clastic-rich bed that is intercalated with red clastic, possibly point to the 
Table 3 General distribution chart of planktonic and large foraminifera within Tanjero and Aqra formations (Early to Late Maastrichtian)

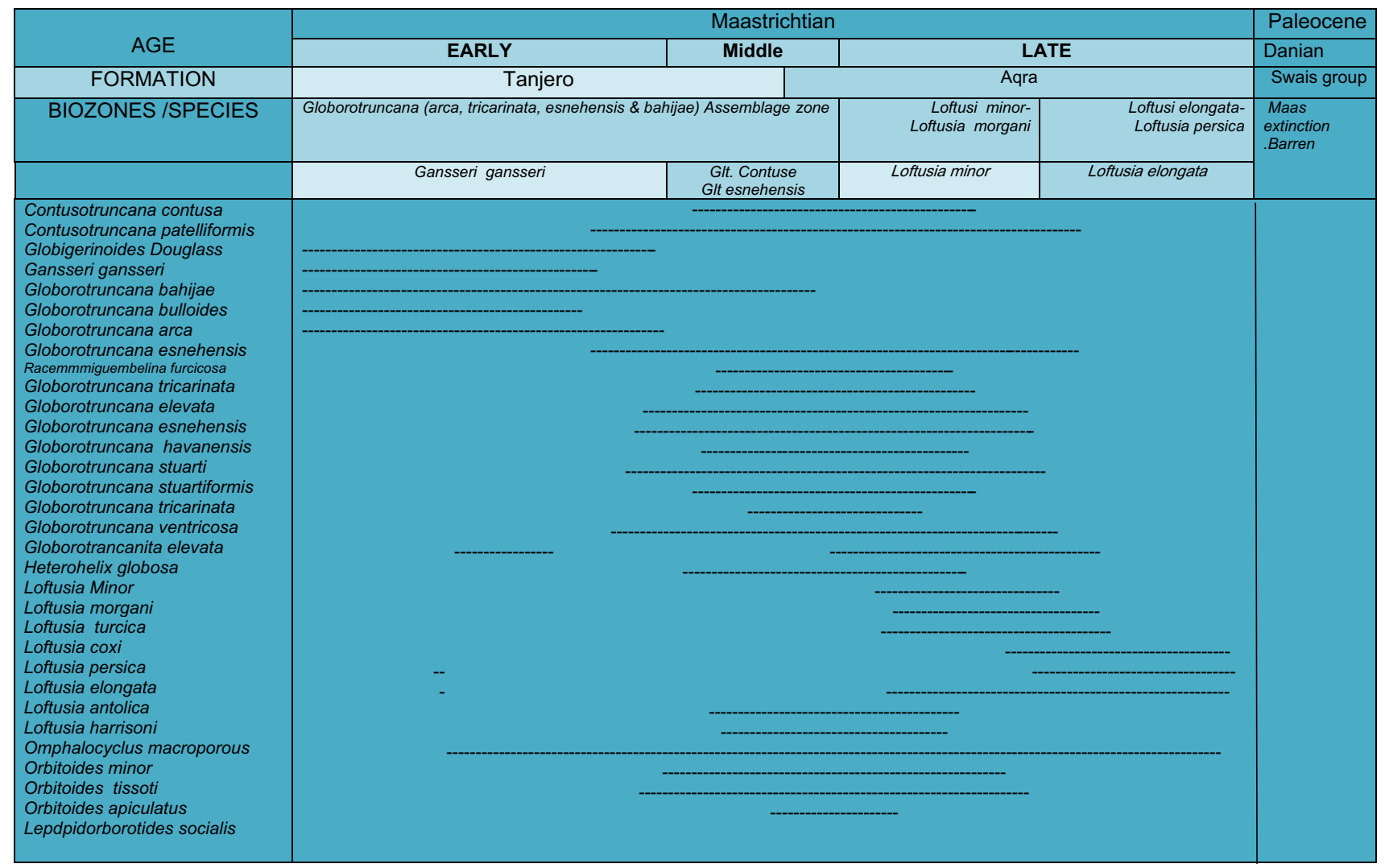

last appearance of rudist and other Maastrichtian fauna and flora, and termination of the Maastrichtian green house, just close to Cretaceous/Tertiary boundary.

\section{Sequence stratigraphy}

In this work, the Late Cretaceous tectonic Megasequence (AP.9) is subdivided into two second-order sequences from the oldest to the youngest ( $\mathrm{Cr}$. A and Cr. B). The secondorder sequence (Cr.B) mostly comprises three third-order sequences and involves the Late Campanian to Late Maastrichtian supersequences. The late Campanian-Late Maastrichtian supersequences manifest the upper part of the Late Turonian-Danian Megasequence (extending for a $19 \mathrm{Ma}$ time span), while the lower part is of Late Turonian-Early Campanian age (from 75.0 to $66.0 \mathrm{Ma}$ ), covering a $9 \mathrm{Ma}$ time span (Sharland et al. 2004; Jassim and Goff 2006; Aqrawi et al. 2010; Lawa et al. 2013). Generally, sequences are subdivided into system tracts based on objective criteria including types of bounding surfaces, parasequence-set distributions and the position within sequences (Wagoner 1995; Posamentier et al. 2009). System tracts geometry and facies associations are the main building blocks in reconstructions of the palaeo-sequences framework. Based on that, we recognize that in Sulaimani, Erbil and part of Kirkuk Province, the Shiranish, Tanjero and Aqra formations together comprise one second-order depositional sequence (Fig. 2). Meanwhile, this sequence in the Kurdistan platform is represented by the Bekhme, Aqra and/or Shiranish formations, especially in Bekhme, Aqra and Dhouk provinces (Figs. 2, 8). The studied second-order supersequences are subdivided into three third-order depositional sequences that start from the Late Campanian to the Late Maastrichtian and are characterized by progressive shallowing upwards from deep open marine conditions (more than $800 \mathrm{~m}$ ) during the Late Campanian to a few metres to subaerial erosions by the Late Maastrichtian. A sequence boundary of type one, about $250 \mathrm{~m}$ thick, consists mainly of a conglomerates-filled incised valley capped with Cretaceous supersequences. This indicates a sequence boundary type one of huge incised valley nature between Tectonomegasequence (TMSAP 9-Late Cretaceous) and the base of the Tectonomegasequence (TMSAP 10-Paleogene). The base of this second-order depositional system is represented by a Middle Campanian unconformity between the Kometan and Shiranish formations which also indicate obduction of the Neotethys margin onto Arabian plate generation and development of the Kurdistan foreland basin (Lawa et al. 2013; Aqrawi et al. 2010, Table 2). The glauconite bed has a regional distribution and 
acts as regional datum for an even gap or sequence boundary (Wagoneer 1995; Posamentier et al. 2009; Loutit et al. 1988; Haq 1991; Haq et al. 1988, Fig. 3, 1-2). The filling of the Kurdistan foreland basin shows a variable rate of subsidence from the proximal towards the depocentre, as well as along the Zagros major trends based on the aforementioned facies associations; we may conclude that the basin had a higher subsidence rate in Sulaimani and Erbil than in the Aqra, Bejil and Dhouk areas. Saura et al. (2011) recognized similar variations from the Amiran foreland basin (within the Iranian Zagros fold thrust belt) with an average subsidence rare of $\sim 0.16 \mathrm{~mm}$ per yr. That was possibly controlled by the southwards migration of the depocentre and basement block movements (Lawa 2004; Lawa et al. 2013; Ali et al. 2014; Ahmad 2014; Burberry 2015). In this work, we consider that the last second-order depositional system starts with major transgression and retrograded parasequences to fill the huge accommodation space, with sudden drowning of the Neotethys basin and the development of a starved basin. These develop through three maximum flooding surfaces (MFS), namely MFS 175, MFS 180 and MFS 190, in correlation with the Arabian plate margin sequence stratigraphic framework (Sharland et al. 2004; Aqrawi et al. 2010; Jassim and Goeff 2006). The three third-order deposition systems comprise the Late Campanian-Maastrichtian second order, which is represented by: 1-Late Campanian-Early mostly Maastrichtian Shiranish third order; 2-Early Maastrichtian to Middle Maastrichtian Tanjero third order; 3-Middle to Late Maastrichtian Aqra third order, and described as follow.

\section{The first third order is represented by the whole of the Shiranish formation in the imbricated and high folded thrust zone sections which are subdivided into two fourth orders}

The Late Campanian fourth-order and the Early Maastrichtian fourth-order depositional parasequences can be correlated with Globotruncana aegyptiaca (Late Campanian), Gansserina gansseri (Latest Campanian-Early Maastrichtian) and Contusotruncana contusa (Early Maastrichtian) planktonic foraminiferal biozones (Table 3). They are associated with two benthonic zones of Bolivinoides decorates of the Late Campanian fourth order and the Early Maastrichtian biozone of Bolivinoides draco and Bolivinoides miliaris, which comprise the second fourth order within this third order, as recognized by Jaff et al. (2014). The global changes in sea level at the Campanian/Maastrichtian boundary coincide with the boundary between the first and second fourth orders within the Shiranish formation (first third order). The first parasequences are characterized by planktonic mudstone facies and are bounded at their bases by a hard ground surface from the Middle Campanian gap (Aqrawi et al. 2010) A transgressive system tract (TST) results from the rapid drowning of the basin, underlain by the transgressive surface and capped by a drowned lap surface or maximum flooding surface. The sequence boundary of type one at the base of the first third order is characterized by thick glauconite, with extensively bioturbated intervals combined with the presence of significant extra-terrestrial components, as cherts and carbonate fragments are recorded in several sections (Dokan, Merga pan, Qarasirt, Choman) and at Taq Taq well. Rapid drowning of the Kurdistan foreland basin created a huge accommodation space with a slow rate of deposition and a slow rate of sediment supply and acted as a starved basin. The main parasequence building unit is comprised of very thick interval of marl or shale with thin morally limestone occasionally. The low-stand system tracts (LSTs) are thinnest in the basin margin and thickest towards the basin centre; that is why they are in the imbricated section (Mokaba, Alasiwa, Bazgeer, Kona massi sections), because much of the basin margin is undergoing erosion, while in the high folded zone the low-stand system tract occupies the lower part of the Shiranish formation and combines with the increasing Shiranish formation's thickness from $100 \mathrm{~m}$ on average (IZ) to $170 \mathrm{~m}$ in the high folded zone (Dokan, Qarasirt and Qaradagh wells). The turnover to the transgressive system tract occurs at short time intervals and leads to short low-standing system tracts. The transgressive system tract includes those deposits accumulated between the transgressive surface and maximum flooding surfaces. The switching is from a progradational to an aggradational stacking pattern and shows a landward stepping depositional pattern and a basin margin overlap due to a relative rise in sea level. The monotonous deposition of blue marl with marly limestone of planktonic mudstone and wackestone microfacies predominates in all sections and study wells, with remarkable thickening towards the depocentre (Fig. 3, 1-7). The predominance and diversity of the planktonic foraminifer are related to Globotruncana aegyptiaca and Gansserina gansseri assemblages which indicate MFS $175 \mathrm{Ma}$ and point to condensed sections which are most extensive in such conditions. The monotonous repetitions of marl in each parasequence with very minor facies shifts show the predominance of an aggradational stacking pattern without landward or basinward shifts within the lower and middle parts of the Shiranish formation, and this indicates stagnant starved basin conditions and mineralized pyritic (Table 2; Fig. 3, 1-5). The early highstand system tract during the Early Maastrichtian notably shows a decrease in the planktonic/benthoic ratio and is combined with increasing carbonate beds, as well as decreasing marl beds, from both the thickness and frequency points of view, and this points to a slow rate of sea level rise while the depositional rate exceeds it (Table 3). The aggradational stacking pattern changes to 
a progradational stacking pattern and mostly indicates a late highstand system tract capped by a sequence boundary of type 2 . Accordingly, the second fourth order of the Early Maastrichtian age points to a shallowing upwards cycle that is manifested by the predominance of Bolivinoides benthonic foraminifera within a more limestone porn parasequence. The variations from an upper bathyal depositional environment, towards an outer-, then middle- to inner-shelf setting point to a decrease in the palaeodepth (from more than 800 to less than $300 \mathrm{~m}$ ) and almost coincide with a regional sea level fall at the Campanian/ Maastrichtian boundary (Darvishzad and Abdolalipour 2009; Sharalnd et al. 2004; Wagoner 1995; Posamentier et al. 2009). The top of the Shiranish third order coincides with a mass extinction surface and is characterized by a turbidite facies with bioturbated sandstone bed that points to a sequence boundary of type two overlain by a shelfmargin system tract. Awdal et al. (2014) propose that the NE-SW fracture in the Shiranish formation set (joints) was formed in a foreland setting and controlled by far-field stresses, whereas later fracturing occurred due to outerarc extension during flexing of the Bina Bawi and Taq Taq anticlines.

\section{The Early to Middle Maastrichtian second third order is represented by the middle and upper parts of the Tanjero formation ( $1000 \mathrm{~m}$ thick) and excludes the uppermost parts (100-200 m)}

The Tanjero formation has been studied from a sequential stratigraphic point of view by Minas (1997) who includes the lower and middle parts as (TST) and (HST), respectively. In this work, we recognize that the Tanjero formation consists of a shelf-margin system tract (SMST, TST and HST) and extends from the Late Early Maastrichtian to the Early Late Maastrichtian, in both zones (IZ) and (HFTZ), while, remarkably, it disappears in the LFTZ and towards the Kurdistan platform. The shelf-margin system tract is characterized by a low-stand wedge and land-stand fans that are rich in pebbly sandstone conglomerates and breciated or slumped rudist fragments (especially in the IZ sections, Fig. 4, 4-8) with a $\mathrm{Ta}-\mathrm{Tb}$-dominated coarse Baume sequence that alternates with deep marine planktonic-rich marl facies. The retrogradational stacking pattern shows a progressive increase in deep facies which overlies shallow facies, and this points to rapid transgressions and progressive increase in marl facies with a fine sandstone bed that indicates distal facies. The maximum flooding surface, MFS 180, at the top of the transgressive system tract (TST) is represented by $20-50-\mathrm{m}$-thick marl and shale beds that are very rich in planktonic foraminifera of the Gansserina gansseri zone and associated with a condensed section that is rich in deep planktonic foraminifera (Fig. 4, 9-11). The highstand aggradational stacking pattern is characterized by a thick marl bed and very thin bioturbated sandstone that is characterized by Bouma horizons of $\mathrm{Td}$ and Te. The late HST shows a shallowing upwards overall parasequence, hence a progressional stacked parasequence associated with increasing proximal turbidites. A pebbly sandstone bed about $2-5 \mathrm{~m}$ thick, with a ball and pillow sedimentary structure, alternates with sandy to a sea level fall during the Late Maastrichtian. That is also manifested by the SBT2 at the boundary between the Tanjero and Aqra formations (Fig. 5, 2-5). This boundary combined by the disappearance of the planktonic foraminifera (outer-shelf depth more than $150 \mathrm{~m}$ ) and appearance of large foraminifera, with predominance of Hippurites, indicates variation in water depth from tens to only few metres.

\section{The last third depositional order is represented by the Aqra formation or inter-fingering of the Aqra and Tanjero formations at the uppermost 100- $200 \mathrm{~m}$ of the study supersequences}

This part represents the low-stand system tract of the Aqra outer ramp facies association and is distinguished by poorly sorted, mud-rich sediment, to well-sorted and cross-bedded grainstones, and this was reported from many Late Cretaceous open shelf settings (Breyer 1991; Skelton et al. 1995). This facies succession might reflect the inability of rudist lithosomes to withstand high levels of hydrodynamic energy. The lower parasequence of the LST is occupied by lowstand fans and wedge deposits that are mixed with outer ramp carbonates at depths mostly less than $200 \mathrm{~m}$, with a remarkable disappearance of or reduction in planktonic foraminifera and a remarkable increase in large and benthic foraminifera like Omphalocyclus, Lepidoorbitoides, Orbitoides and Loftusia within thin carbonates alternating with coarse clastics (Figs. 5, 11-13, 6, 1-4). The mixed siliciclastic-carbonate parasequence consists of pebbly sandstone at the base with large foraminifera, and then changes upwards to silty marl and then to carbonates with rudists. The following transgressive surface is indicated by carbonate beds increasing in thickness and frequency. The transgressive system tract (TST) is characterized by carbonate beds increasing in thickness and decreasing in clastics, capped by MFS 190, as indicated by the Loftusia-Orbitoides zone (Fig. 6, 1, 5). The reefal facies indicates an HST and points to an aggradational stacking pattern that is associated with the accumulation of the thickest carbonate sequence during the Late Maastrichtian time within the foreland basin. The rudist carbonate parasequence consists of few decimetre to few metres carbonates. They changes from argillaceous limestone to locally boundstone or Biostrom (Fig. 6, 1-5). The patchy rudist reefs also combine with a predominance of giant pelecypods, gastropods and echinodermata in all sections of the imbricated zone; these are less developed in the high folded thrust zone but still there, as mentioned 
by Bellen et al. (1959), Aqrawi et al. (2010), Lawa et al. (1998) and these indicate a palaeodepth of less than $25 \mathrm{~m}$ (Al-Ameri and Lawa 1986). A progressive sea level fall by the late HST points to a progradational stacking pattern parasequence of fine-grained, lagoonal sediments (Fig. 6, 6-8). These shallow lagoonal environments were intermittently colonized by gastropods Acteonella banks (Fig. 6, 7, 8) and locally by rudist, if conditions were favourable for them. The last parasequence is characterized by bioclastic carbonates and thin bedded carbonates, changes upwards to siliciclastics (Fig. 7, 1-3; 8-10). The late HST is characterized by a progradational stacking pattern and occasional intercalation of siliciclastic types with a thin carbonate bed and a few red clastic influxes (Ameen and Gahrib 2014). The upper boundary corresponds to a sequence boundary type one (SBT1) at the base of the Dainan and is supported by: 1-Disappearance of flysch facies and/or reefal facies of the Late Maastrichtian that are overlain by continental facies of the Swais Group; 2-Extinction of more than 200 species of Maastrichtian planktonic and benthonic foraminifera including Globotruncanides and Heterohelicides; Textularide, Bolivinoides and Uvegernides, Ataxophragmides; 3-Extinction of all the Late Cretaceous large foraminifera, such as Loftusia, Omphalocyclus, Orbitoides, Lepidorbitoides, Gyroconulina, Pseudochrysaldina and Cuneolina; 4-Disappearance of giant and gregories gastropods (Turritella and Acteonella) and Hippurites (Radiolits, Preradiolites and Euradiolites, Daurina); 5-Disappearance of green calcareous algae (Dasycladaceae, Cymopolia and Trinocladus); 6-Disappearance of all coral Cyclolites, Exogyra, Gryphaea, inoceramids, echinodermata, ammonites and other reef habitats (Fig. 7, 1-12, Table 2) Such extinction phenomena were also recorded on the Kurdistan platform and point to more regional unconformities at the Cretaceous/Tertiary boundary (Lawa 1983; Al-Omari et al. 1989; Al-Bana 2010), where only $9 \mathrm{~m}$ of Kolosh formation overlies Aqra formation in Geli Sheikh Abdul Aziz. The termination of whole study successions by a major incised valley and unconformity (Fig. 7, 1-3) coincides with all published papers on the Arabian plate margin (Lawa et al. 1998; Ali et al. 2014; Sharland et al. 2004).

\section{Discussion}

The Late Campanian-Maastrichtian siliciclastic-carbonate sequence, within the Kurdistan foreland basin, indicates a major second-order depositional system that was laid down on the southern-side edge of the Neotethys Ocean (Zagros area) and shows the influence of both tectonic and eustatic sea level changes on facies associations, parasequence stacking patterns and cyclical alternations in depositional systems. The three maximum flooding surfaces, MFS 175, MFS 180 and MFS 190, and sequence boundaries coincide with those recorded on the Arabian plate margin by Sharland et al. (2004), Aqrawi et al. (2010), Jassim and Goff (2006). The second-order depositional system involves three thirdorder depositional systems, the lower first third order points to a starved basin that was filled with planktonic-rich mudstone with an almost retrogradational to aggradational stacking pattern. The second third order is characterized by flysch facies evolved from SMS to TST and rapid HST, that die out in the Zagros trend and towards the Kirkuk embayment (depocentre). The third order shows a progradational stacking pattern that indicates continuous shallowing upward cycles within patch-reef and mixed coarse clastics. The maximum clastics influx enters the Kurdistan foreland basin from the rising mountain belt (Qulqula and ophiolites hinterland) left most of the sediment as thick accumulations proximal to the mountain front, filling the huge accommodation space via a high subsidence rate. The whole thickness of the measured supersequences reaches more than $2000 \mathrm{~m}$ in the imbricated and high folded thrust zone sections and decreases to less than $400 \mathrm{~m}$ in the Kirkuk embayment wells (Sarqala, Jambur and Kurda Meer wells, Fig. 9). The progressive migration of a deformational front and a foreland basin enhanced by basement blocks movement (Khanaqin and Greater Zab faults) are the controlling factors in the depositional style and palaeo-geographic facies distributions. The huge conglomerates at the top of this sequence, which is about $250 \mathrm{~m}$ and capped by the Late Cretaceous sequence of the imbricated zone that reduces to $32 \mathrm{~m}$ in the HFZ, can be considered the largest incised valley in the whole Zagros fold thrust belt. Mostly, a sequence boundary type one always reflects tectonic activity during deposition (Vail et al. 1977; Emery and Myers 1996; Einsele 2000); therefore, they probably reflect the influence of the Laramide uplift model, especially when the rate of sediment accumulation exceeds the rate of accommodation generation. Posamentier et al. (2009) clarify such conditions from the upper Cretaceous foreland basin of south-western Wyoming (USA). Ahmad (2014) in his tectonostratigraphic study of the Zagros folded thrust belt, emphasized that syn-tectonic activities are responsible for the NE-SW set of fractures in the upper part of the Tanjero and Aqra formations. Actually, the facies assemblage found in this study (within the Aqra-Tanjero interval) is comparable to the facies assemblages of other upper Cretaceous shallow water carbonates of the Peri-Adriatic domain (Carboneef et al. 1971; Ruberti 1991; Carannante et al. 1993). During the Late Cretaceous and Early Palaeocene, former graben structures were elevated as a result of inversion tectonics. Inversion occurred both within and at the margins of the basin, and the reactivation of older faults took place during the Turonian and Danian (Ahmad 2014; Aqrawi et al. 2010; Sharland et al. 2004). Accordingly and taking into consideration the facial association changes, biostratigraphic zonation and lithostratigraphic markers, the effects of the 


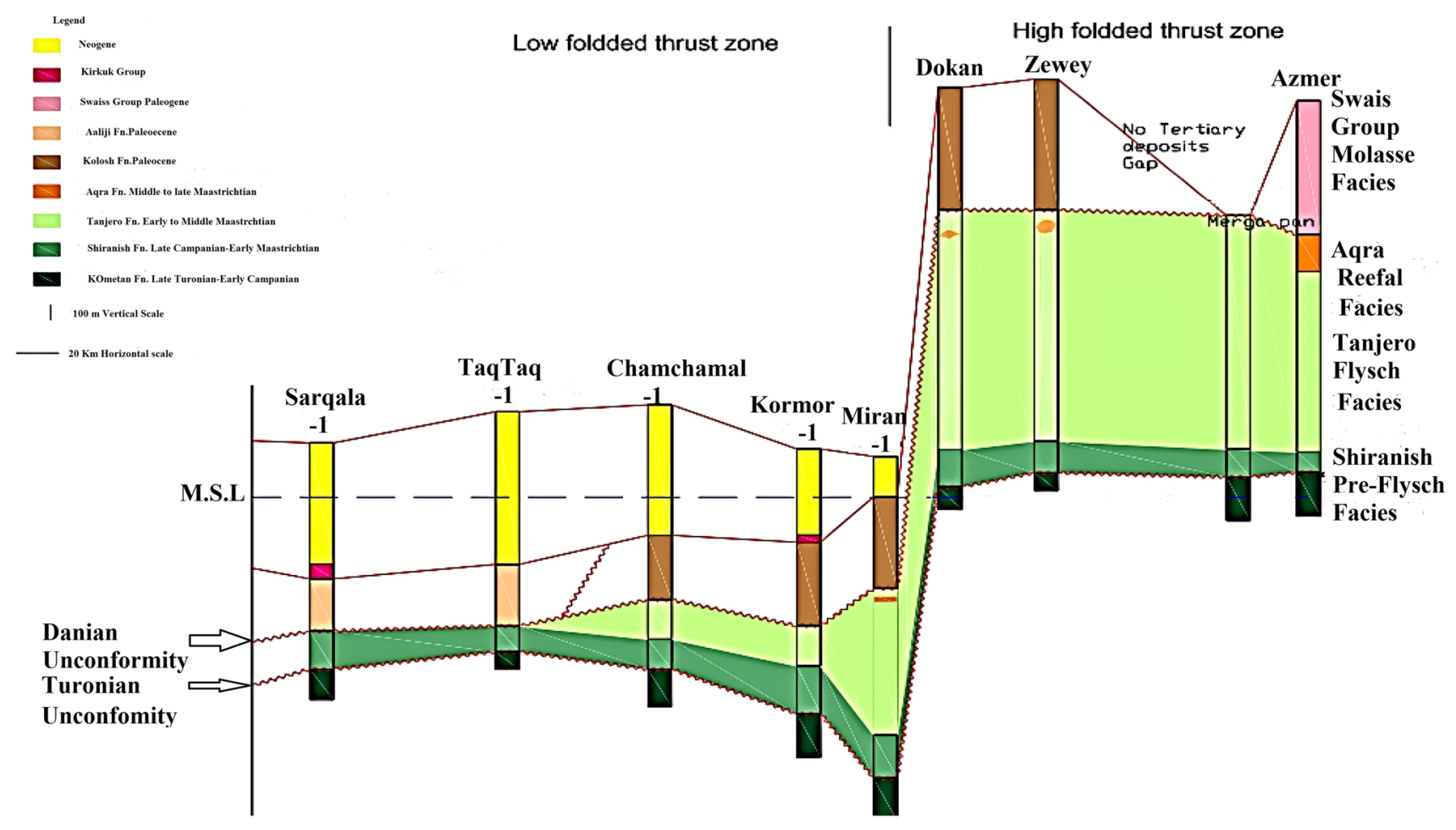

Fig. 9 Lateral and vertical lithostratigraphic variations in the studied sections and wells

Sirwan (Khanaqin) fault and Greater Zab deep-seated fault were proposed as controlling factors of the palaeo-configurations and palaeo-geographic distribution of the trough and platform settings. Also, Burberry (2015) mentioned that the surface anticlines and location, as well as a number of facies changes within the cover sequences, are constrained by the interaction of the Najd, Traverse and Nabita trend fault, among them the Greater Zab fault. Zebari and Burberry (2015) also concluded that the basement Hader-Bekhme Fault which is proposed beneath the Greater Zab separates the two different types of Cretaceous facies. Therefore, the reactivations of the basement faults control the boundary of Kurdistan foreland basin. Al-Mehaidi (1975) and recently Aqrawi et al. (2010) and Ahmad (2014) all emphasized the progressive increase in tectonic influence from the Late Cretaceous. The most important changes are those that control the flysch facies association which disappears in both the north-west Zagros trend and south-west depocentre trend. During the last third order, the amplitude of sea level fluctuations probably ranges between a few metres and a few tens of metres. This confirms models which suggest lowamplitude sea level variations during "greenhouse" times (Read 1995). The cycle formation was dominated by allocyclic processes in the realm of the inner platform. However, towards the platform margins, intrinsic factors (such as sediment working and lateral migration of shoals) became more important, and the allocyclic signals were therefore much more difficult to recognize as motion was deposited in the central part of the basin. The sequence- stratigraphic evolution of carbonate platforms reflects sea level changes, sediment production and basin palaeo-configurations. Therefore, cyclic alternations of proximal turbidites and rudist carbonates occupy the Late Cretaceous time span. During the Maastrichtian greenhouse and stable conditions, shallow warm water (mostly less than $25 \mathrm{~m}$ ), the Hippurites (rudist) patchy reef and large foraminifera flourished and indicate the prograding of carbonate facies over turbidites, and when the tectonic pulse increased, the coarse clastics from the ophiolite and radiolarites accretion prisms invaded and drown the rudist communities; such conditions are also recognized by Abdelghany (2003) from Oman section. So, during the Kurdistan foreland basin, the maximum disturbance occurred during the deposition of the Tanjero formation that shows a progressive last regression of the sea by the end of the Maastrichtian and indicates decrease in palaeo-depositional environments' depth during variable tectonic rates. 


\section{Conclusions}

1. The Late Campanian-Late Maastrichtian (76-66 Ma) supersequences within the Kurdistan foreland basin are represented by a second-order depositional system that involves the geo-history of three third-order depositional systems, starts with deep open marine marl porn facies of the Shiranish formation and changes upwards to the flysch facies of the Tanjero formation, and these are terminated by the rudist porn facies association of the Aqra formation. A sequence boundary of type one (SBT1) at the base of this end order points to a middle Campanian unconformity surface as the Arabian plate margin and a sequence boundary of type one as a major incised valley with more than $250 \mathrm{~m}$ of conglomerate capping the Maastrichtian and considered as the major unconformity at the Arabian plate margin.

2. Three maximum flooding surfaces were recorded as MFS175 at the middle part of the Shiranish formation, while MFS180 manifests the last planktonic mudstone bed of the Tanjero formation and MFS 190 the base of three middle ramp facies of the Aqra formation.

3. The flysch facies palaeo-geography is mostly very thick in the imbricated zone sections, reduces towards the high folded thrust zone and finally dies out towards both the depocentre (Kirkuk embayment) and the Kurdistan platform. Such a palaeo-geographic setting is mainly controlled by the Sirwan fault and the Greater Zab fault, where Bekhme and Aqra formations predominate instead of the Tanjero and Shiranish formations.

4. The Kurdistan foreland basin shows facies associations that change from pre-flysch and flysch to reef and molasses from the Late Campanian to the Palaeogene. This was integrated by a major shallowing upwards cycle during the Early Maastrichtian from a depth of $800 \mathrm{~m}$ to less than $10 \mathrm{~m}$ in the Late Maastrichtian, where a rudist ramp developed and then became zero at the Maastrichtian/Danian boundary. The overfilling continental deposits of the Swais Group (Palaeogene) in the imbricated zone were separated by positive land from the pen contemporaneous Kolosh flysch facies within the high Zagros fold thrust successions.

5. Eustatic sea level changes integrated with the propagation of the Zagros front, and basement block movements generally controlled accommodation space generation and extinction and facies-stacking patterns of the second- and third-order depositional systems, while eustatic sea level changes were more effective in the fourth orders.

6. The rudist reefal facies of the Aqra formation (Maastrichtian) may be considered as an important newly recognized reservoir in the Kurdistan foreland basin, in addition to other Late Cretaceous reservoirs (Kometan and Shiranish formations).

Open Access This article is distributed under the terms of the Creative Commons Attribution 4.0 International License (http://creativecomm ons.org/licenses/by/4.0/), which permits unrestricted use, distribution, and reproduction in any medium, provided you give appropriate credit to the original author(s) and the source, provide a link to the Creative Commons license, and indicate if changes were made.

\section{References}

Abdelghany O (2003) Late Campanian-Maastrichtian foraminifera from the Simsima formation on the Western side of the Northern Oman mountains. Cretac Res 24:391-405

Abdel-Kireem MM (1986) Contribution to stratigraphy of the upper cretaceous and the lower tertiary of the Sulaimani. NE Iraq $\mathrm{N} \mathrm{Jb}$ Geo Paleonto Abh 172(1):121-139

Agard P, Omrani J, Jolivet J, Mouthereau F (2005) Convergence history across Zagros (Iran): constraints from Collision and earlier deformation. Int J Earth Sci 94:401-419

Ahmad SH (2014) Tectonostratigraphy of the Mesozoic from Zagros fold thrust belt. University of Paris 6, unpublished $\mathrm{PhD}$ thesis

Al Hamdani A (2015) Pseudo-bedding and burrow silicification in Kometan formation of the Dokan Area, northeastern Iraq. Aarab J Geosci 8(1):325-333

Al-Rawi IK (1981) Sedimentology and petrography of Tanjero clastics formation from north and NE, Iraq. Unpub. Ph.D. Thesis, University of Baghdad

Al-Ameri T, Lawa FA (1986) Palaeoecological model and faunal interaction within Aqra Limestone Formation, North Iraq. J Geol Soc Iraq 19(3):7-27

Al-Banna NY (2010) Sequence stratigraphy of the Late CampanianEarly Maastrichtian Shiranish Formation, Jabal Sinjar, northwestern Iraq. GeoArabia 15(1):31-44

Ali S, Mohammad M, Aswad K, Ismail S, Buckman S, Jones B (2014) Tectono-stratigraphy and general structure of the northwestern Zagros collision zone across the Iraq-Iran border. J Environ Earth Sci 4(4):92-110

Al-Mehaidi HM (1975) Tertiary nappe in Mawat Range, N.E Iraq. J Geol Soc Iraq 8(1):31-45

Al-Mutwali MM, Al-Haidary LY (2012) Foraminiferal biostratigraphy of Bekhme Formation (Late Campanian) in Dohuk Area/ Northern Iraq. Iraq Nat J Earth Sci 12(3):41-72

Al-Omari FS, Al-Radwani M, Lawa FA (1989) Biostratigraphy of Aqra limestone formation (Upper Cretaceous); Northern Iraq. J Geol Soc Iraq 22(2):44-55

Al-Qayim B, Al-Mutwali M, Nissan B (2008) Flysch-Molasses sediments of the paleogene foreland Basin of north Arabia, Shiranish Area, North Iraq. Iraqi Bull Geol Min 4(2):121-139

Al-Qayim B, Ibrahim AO, Koyi H (2012) Tectonostratigraphic overview of the Zagros Suture Zone, Kurdistan Region, Northeast Iraq. GeoArabia 17(4):109-156

AL-Wazan AM (2007) Planktonic foraminiferal biostratigraphy of kolosh formation (Paleocene) in Dohuk Area North Iraq. Unpublished M.Sc Thesis, University of Mosul, Iraq, p 68

Ameen FA, and Gharib H (2014) Biostrtaigrapahy of the tethyan cretaceous successions from Northwetern zagros fold-thrust belt, Kurdistan region, NE-Iraq. Arab J Geosci 7(7):2689-2710

Aqrawi AAM, Goff JC, Horbury AD, Sadooni FN (2010) The petroleum geology of Iraq. Scientific Press, Beaconsfield, p 424p 
Awdal AH, Braathen Wennberg OP, Sherwani GH (2014) The characteristics of fracture networks in the Shiranish formation of the Bina Bawi anticline, Comparison with TaqTaq Field, Zagros, Kurdistan Region, NE/Iraq. Petrol Geosci 19:139-155

Aziz BK, Lawa FA, Said BM (2000) Sulaimani seismic swarm during spring 1999, NE Iraq. J Zankoy Sulaimany 4(1):97-100

Bellen RCV, Dunnington HV, Wetzel IR, Morton D (1959) Lexique startigraphique international Asie, Iraq. 3(10a)

Berberian M (1995) Master "blind" thrust faults hidden under the Zagros folds: active basement tectonics and surface morphotectonics. Tectonics 241:193-224

Breyer R (1991) Das Conica der nordlichen Provence (Rhodanienne) Stratigraphie Rudistenfazies und geodynamische Entwicklung, Arbeiten. Geowissenschaftliche 9:336p

Buday T (1980) The regional geology of Iraq, vol 1, stratigraphy and paleogeography. In: Kassab IIM, Jassim SZ (eds) SOM, Baghdad

Burberry CM (2015) The effect of Basement fault reactivation on the Triassic-recent geology of Kurdistan, north Iraq. J Pet Geol 38(1):37-58

Burberry CM, Jackson CAL (2011) Late cretaceous to recent deformation, related to inherited structures and subsequent compression within Persian gulf; A 2D seismic case study. J Geol Soc Lond 168:485-498

Carannante G, Roberti D, Simone L (1993) Rudist and related sediments in Late Cretaceous open shelf settings. A case history from the Mateese area (Central-Southern Apennines, Italy). Giorn Geol $55: 21-36$

Carboneef F, Praturlon A, Sirna G (1971) The Cenomanian shelf edge facies of Reccoa de Cave (Prenestini Mts., Lattium). Geol Romana 10:131-198

Darvishzad B, Abdolalipour S (2009) Campanian and Maastrichtian biostratigraphy and paleo environment in Jorband section, North of Iran. J Sci, Islamic Repub Iran 20(1):23-39

Einsele G (2000) Sedimentary basin, evolution, facies and sediment budget, 2nd edn. Springer, Berlin

Emery D, Myers K (1996) Sequence stratigraphy. Blackwell Scientific Limited, New York

Haq BU (1991) Sequence stratigraphy, sea level change and significance for deep sea. Spec Publ Int As Sedim 12:12-39

Haq BU, Hardenbol I, Vial PR (1988) Mesozoic and Cenozoic chronostratigraphy and cycles of sea-level change. In: Wilgus CK, Hastings BS, Kendall CG, Posamentiar HW, Ross CA, Van Wagoner JC (eds) Sea-level changes: an integrated approach. Society of economic palaeontologists and mineralogists. Special Publication, Tulsa, pp 71-108

Jaff RBN, William MSI, Lawa FA, Lee S, Jan A (2014) A refined foraminiferal biostratigraphy for the Late Campanian-Early Maastrichtian succession of northeast Iraq. GeoArabia 19(1):161-180

Jaff RBN, William MSI, Lawa FA, Lee S, Jan A (2015) Biostratigraphy and palaeoceanography of the early Turonian-early Maastrichtian planktonic foraminifera of NE Iraq. J Micropalaeontol 34(2):105-134

Jassim SZ, Goff JC (2006) Geology of Iraq. Dolin, Prague and Moravian Museum, Berno, p 341p

Jaza IM (1992) Sedimentary facies analysis of the Tanjero Clastic Formation in Sulaimaniya district, northeast Iraq. Unpublished MSc thesis, Salahaddin University

Karim KH (2004) Basin analysis of Tanjero Formation in Sulaimaniya area, NE Iraq. Unpublished $\mathrm{PhD}$ thesis, University of Sulaimani University

Kassab IIM (1975) Biostratigraphy of upper cretaceous lower tertiary of North Iraq. Colloque Africaia de Micropaleontology 1:277-325

Kassab IIM (1979) The genus Globotruncana Cushman, from the upper cretaceous of Northern Iraq. Geol Soc Iraq 2:27-127
Kuhn A, Kumel S (1939) Die geologischen, Die fauna Verhaltnisse des Dschebel Akra in Iraq Oberkreide aus kurdistan. Die JB Beil Bd 80:75-89

Lawa FA (1983) Microfacies of the Aqra formation in its type section. Msc thesis, Mosul University

Lawa FA (2004) Sequence stratigraphic analysis of the Middle Paleocene-Middle Eocene in the Sulaimani District (Kurdistan Region). Unpublished PhD thesis, University of Sulaimani

Lawa FA, Al-Omari FS, Radwani MT (1986) Restudy of the Genus Gyroconuliana from Aqra formation. J Geol Soc Iraq 19(3):77-87

Lawa FA, Al-Karadakhi AI, Ismail KM (1998) An interfingering of the upper cretaceous rocks from Chwarta-Mawat Region, NE Iraq. Iraqi Geol J 31(2):33-45

Lawa FA, Koyi H, Ibrahim A (2013) Tectono-stratigraphic evolution of the NW segment of the Zagros fold-thrust Belt, Kurdistan, NE Iraq. J Pet Geol 36(1):75-96. https://doi.org/10.1111/jpg.12543

Loutit TS, Hardenbol J, Vail PR, Baum GR (1988) Condensed section: the key to the age dating and correlation of continental margin sequences. In: Wilgus CK, Hastings BS, Kendall CGSC, Posamentier H, Ross CA, Van Wagner J (eds) Sea-level change: an integrated approach, society of economic palaeontologists and mineralogists, Special Publication, vol 42, pp 183-215

Minas HAA (1997) Sequence stratigraphic analysis of the upper cretaceous succession Of Central and Northern Iraq. Unpublished PhD thesis, University of Baghdad

Posamentier HW, Summmerhayes CP, Haq BU, Allen GP, Devlin WJ, Rudolph KW, Shaw CA, Ehman (2009) Sequence stratigraphy and facies associations: special publication 18 of the IAS. In: International association of sedimentologists, Wiley, New York

Read JR (1995) Overview of carbonate platform sequences, cycle stratigraphy and reservoirs in greenhouse and ice-house worlds. In: Read JR, Kerans C, Weber LJ (eds) Milankovitch sea level changes, sea level and reservoirs on carbonate platforms in greenhouse and ice-house worlds: a short course: society of economic paleontologists, vol 35, pp 1-102

Ross DJ (1992) Sedimentology and depositional profile of a Mid-cretaceous shelf edge rudist reef complex. Nahan Ha mearo, Northwest Israel. Sediment Geol 79:161-172

Ruberti D (1991) Facies biocostruite a rudiste nel senonianno del matese aspetti deposizionalie apleoeceologici. Bolletino del Sevizio Geologico de Italia 60:249-258

Saura E, Verge SJ, Homke D, Blanc E, Serra-Kiel JJ, Bernaola G, Casciello E, Fernandez N, Romaire I, Casini G, Embry JC, Sharp IRR, Hunt DW (2011) Basin architecture and growth folding of the NW Zagros early foreland basin during the Late Cretaceous and Early Tertiary. J Geol Soc Lond 168(1):235-250

Sharbazheri KM (2007) Ageing of Unconformity within Tanjero Formation in Chwarta Area Northeast of Iraq (Kurdistan Region). Rafidain J Sci 7(1):37-54

Sharland PR, Archer R, Casey DM, Davies RB, Simmoins MD, Sutcliffe OE (2004) Arabian plate sequence stratigraphy—revisions to SP2. GeoArabia 9:199-212

Skelton PW, Gili E, Vicens E, Obrador A (1995) The growth fabric of gregarious rudist elevators (hippuritids) in a Santonian carbonate platform in the southern Central Pyrenees. Palaeogeogr Palaeoclimatol Palaeoecol 119:107-126

Stevanovitic Z, Miroslav M, Markovitic Y (2003) Hydrogeology of Northern Iraq, UN. FAO Report, 1: 225p, 52, Maps

Vail PR, Mitchum RM, Tod RG, Widmier JM, Hatleid WG (1977) Seismic stratigraphy and global changes in sea level. In: Payton CE (ed) Seismic stratigraphy application to hydrocarbon exploration memoir of the american association of the petroleum geologists, Tulsa, vol 26, pp 49-62

Wagoner VJC (1995) Sequence stratigraphy and marine to non marine facies architecture of foreland basin strata, Book Cliffs, Utah, USA. In: Wagoner VJC, Bertram GT (eds) Sequence stratigraphy

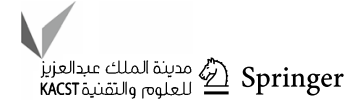


of foreland basin deposits, outcrop and subsurface examples from the Cretaceous of North America: American Association of Petroleum Geologists Memoir, vol 64, pp 137-223

Zebari MM, Burberry CM (2015) 4D evolution of anticline sand implications for hydrocarbon exploration within the Zagros Fold-Thrust Belt, Kurdistan Region, Iraq. GeoArabia 20:161-188
Publisher's Note Springer Nature remains neutral with regard tojurisdictional claims in published maps and institutional affiliations. 